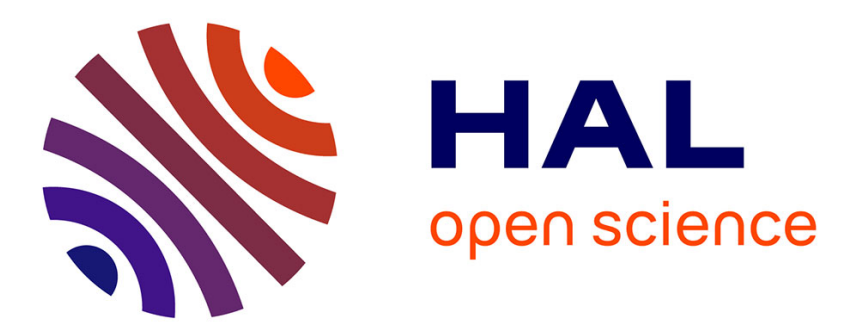

\title{
Technological advances towards extracellular vesicles mass production
}

Alice Grangier, Julien Branchu, Jeanne Volatron, Max Piffoux, Florence Gazeau, Claire Wilhelm, Amanda K.A. Silva

\section{- To cite this version:}

Alice Grangier, Julien Branchu, Jeanne Volatron, Max Piffoux, Florence Gazeau, et al.. Technological advances towards extracellular vesicles mass production. Advanced Drug Delivery Reviews, 2021, 176, pp.113843. 10.1016/j.addr.2021.113843 . hal-03452584

\section{HAL Id: hal-03452584 \\ https://hal.science/hal-03452584}

Submitted on 29 Nov 2021

HAL is a multi-disciplinary open access archive for the deposit and dissemination of scientific research documents, whether they are published or not. The documents may come from teaching and research institutions in France or abroad, or from public or private research centers.
L'archive ouverte pluridisciplinaire HAL, est destinée au dépôt et à la diffusion de documents scientifiques de niveau recherche, publiés ou non, émanant des établissements d'enseignement et de recherche français ou étrangers, des laboratoires publics ou privés. 


\section{Technological advances towards extracellular vesicles mass production}

Alice Grangier ${ }^{1}$, Julien Branchu ${ }^{2}$, Jeanne Volatron², Max Piffoux ${ }^{1,2,3}$, Florence Gazeau ${ }^{1}$, Claire Wilhelm ${ }^{1,4^{*}}$ and Amanda K. A. Silva ${ }^{1 *}$

${ }^{1}$ Laboratoire MSC Matière et Systèmes Complexes, CNRS UMR 7057, Université de Paris, 750013 Paris.

${ }^{2}$ Everzom, 45 rue des Saints-Pères 75006 Paris, France

${ }^{3}$ Department of Medical Oncology, Centre Léon Bérard, Lyon, France

${ }^{4}$ Laboratoire PhysicoChimie Curie, Institut Curie, PSL Research University - Sorbonne

Université - CNRS, 75005 Paris, France.

\section{Abstract:}

Extracellular vesicles (EVs) are becoming essential actors in bio-therapeutics, as much for their regenerative or immunomodulatory properties as for their potential as cargo delivery vehicles. To enable the democratization of these EV-based therapies, many challenges remain such as large-scale production which is necessary to reduce costs of treatment. Herein, we review some advanced works on high-yield EV manufacturing. One approach consists in developing large-scale cell culture platforms, while others focus on cell stimulation to increase particle yield per cell. This can be done by moderate physico-chemical stresses or by disrupting cell membrane towards autoassembled vesicle-like particles. We critically compare these different techniques, keeping in mind that the field still lacks shared characterization standards, underline the importance of therapeutic potency assessment and discuss mass production strategies that have been identified in current clinical trials.

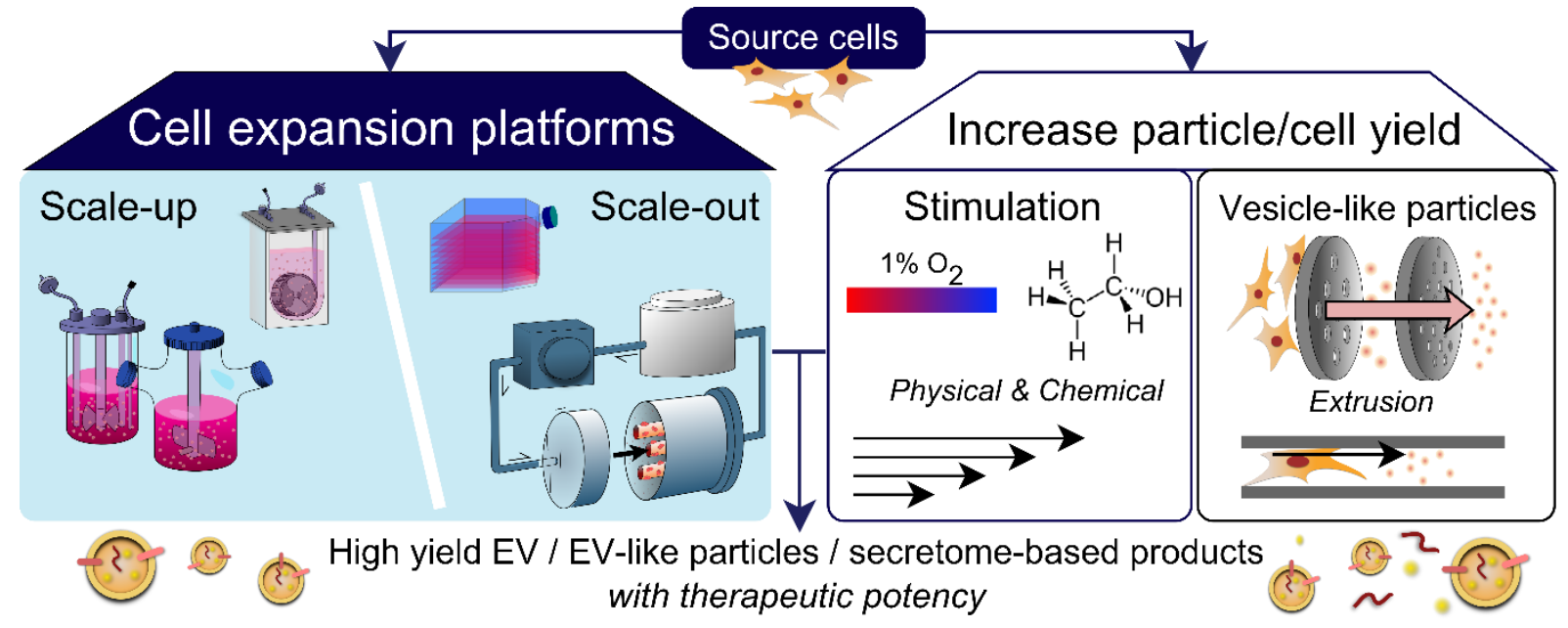




\section{Table of contents}

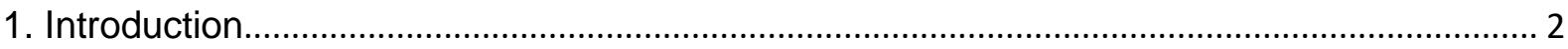

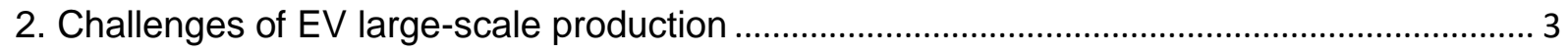

3. Optimized cellular culture: scaling out versus scaling up .................................................... 6

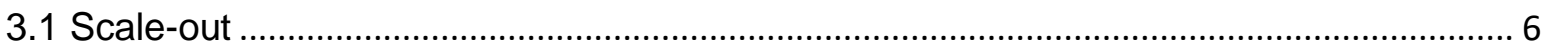

3.2 Scale-up in stirred tank bioreactors and other up-scalable bioreactors .......................... 8

3.3 Adaptation to suspension cells ............................................................................... 8

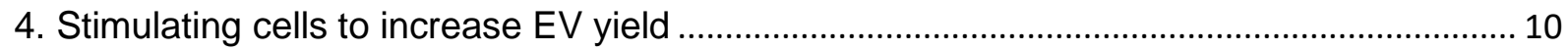

4.1 Physical \& chemical stimulation..................................................................................... 10

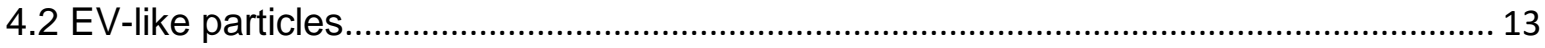

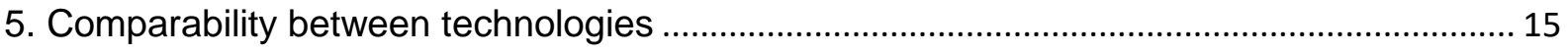

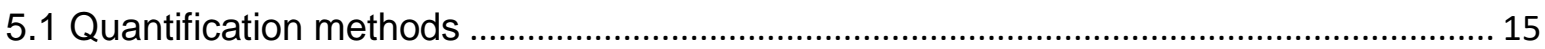

5.2 Definition of a yield parameter and application to large-scale approaches .................... 17

5.3 Evaluation of functional activity of EVs..................................................................... 18

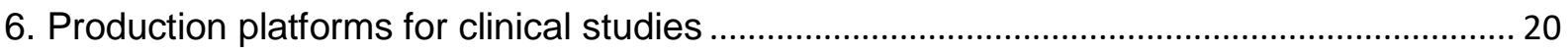

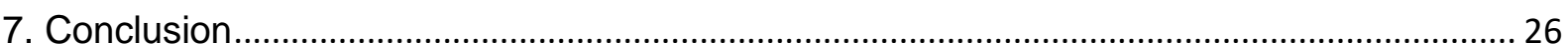

\section{Introduction}

Recently, extracellular vesicles (EVs) have emerged as promising therapeutics, offering a potential cost-effective cell-free and off-the-shelf alternative to cell therapy. EVs, especially from mesenchymal stromal cells (MSCs), hold many promises as they have been regarded as direct mediators of the paracrine effect inducing MSC regenerative properties ${ }^{1,2}$. MSC-derived EVs (MSC EVs) are thus considered as intrinsically bioactive vehicles, which are safely taken up by the organism, mitigating the risks associated with cell injection such as unwanted replication, differentiation and vascular occlusion ${ }^{3}$. Their therapeutic potency in animal studies has been reported in multiple models for the treatment of skin $^{4}$, bone ${ }^{5}$, cartilage ${ }^{6}$, heart ${ }^{7}$, liver ${ }^{8}$, kidney ${ }^{9}$, lungs ${ }^{10}$ and brain ${ }^{11,12}$ among others. Furthermore, EVs have been able to regulate the immune system, enhancing or inhibiting the immune response depending on their parental cell source and of the immune context of the application site ${ }^{13}$, demonstrating a potential use in immunotherapy. In addition to EVs' intrinsic bioactivity, they can also be engineered with specific loading or targeting abilities, adding applications in drug delivery to the list of therapeutic possibilities ${ }^{14}$. For instance, genetic materials ${ }^{15,16}$ or chemotherapeutic drugs ${ }^{17}$ have successfully been loaded within EVs and, as a result, were efficiently delivered to tumors leading to cancer growth inhibition in vivo. EVs from other cell sources than MSCs have also been considered for their clinical applications ${ }^{18}$, both harnessing specific properties of EVs, and the ease of culture or harvest compared to stem cells (e.g. suspension cell lines or plant cells).

In the wake of all these findings, research on EVs has increased almost exponentially these last few years. Since the 1 rst of January 2020 , over $20 \%$ of all EV related articles 
have been published ${ }^{19}$, more than 3,000 patents in English containing "extracellular vesicles" or "exosomes" in their claims have been published ${ }^{20}$, and 23 new clinical trials with EV-products as treatments have been posted ${ }^{21}$. Notably, the active search for COVID 19 treatments also involved EVs since they have been reported as potential regenerative cell-free medicine for acute respiratory syndrome ${ }^{22,23}$.

As a relatively new and expanding field, new scientific guidelines have recently appeared to standardize the report of EV research and advances ${ }^{24}$. However, hurdles have concurrently emerged when beginning the translation of EV-therapeutics to clinical practices ${ }^{25}$. Indeed, high-yield and scalable production or isolation methods still remain rare. Different techniques and processes have recently been proposed to scale up cellular culture ${ }^{26,27}$, such as 3D culture on microcarriers ${ }^{28}$ and the use of hollow fiber bioreactors ${ }^{29}$, or to increase EV yield per cell, including stimulation with chemical agents ${ }^{30}$ or mechanical stress ${ }^{31}$. Another approach is to totally disrupt cell membrane to form biogenic vesicles, which partially mimic EVs regarding membrane composition and intracellular content, and are easily manufactured in much larger quantities ${ }^{32,33}$. In this paper, we will use the term EV-like particles for such vesicles. Tangential flow filtration (TFF) has also been proposed as a promising enrichment technique for large volumes of conditioned media ${ }^{34}$ and size exclusion chromatography (SEC) as a straightforward technique to purify EVs and EV-like particles from soluble factors ${ }^{35}$. Yet, difficulties arise when comparing these techniques because of a lack of standardization and reproducible characterization methods. The need for robust assessment of purity, stability and potency standards is growing rapidly, aiming at developing quality controls for future clinical trials under Good Manufacturing Practices (GMP) requirements.

In this review, we provide an overview of the recent advances that have been proposed to scale up EV production to manufacture safe and cost-effective EVs or EV-like particles. Cell culture platforms allowing massive expansion of source cells are critically discussed and compared, as well as innovative processes to boost the production yield of EVs and EV-like particles. The scale-up strategies in ongoing clinical trials are then presented.

\section{Challenges of EV large-scale production}

For EV-products to be able to replace cell therapy as a safer and more affordable biological medicine, enabling large-scale production of EVs is a major challenge to reduce the costs of $E V$ manufacturing. As an example in cell therapy, dosages between 3 million and 240 million MSCs were reported to have a beneficial effect in preclinical models on big animals (swine and sheep) and clinical models of heart disease depending on the route of administration ${ }^{36}$. One could estimate that an EV dose would be the amount of EVs naturally secreted by the same number of cells which would require the culture of between one and one hundred $150 \mathrm{~cm}^{2}$ flasks. In the optics of treating large cohorts of patients, different strategies can be adopted and combined to obtain the required quantity of EVs.

The most straighforward way is to directly scale up or scale out cell culture platforms, which has already been done in other fields such as monoclonal antibody manufacturing ${ }^{37}$. This includes other 2D supports such as hyperflasks or roller bottles, 
and 3D culture methods generally refered to as bioreactors (e.g. perfusion, fixed bed or spinner flasks), represented in Figure 1. In these approaches, the stakes are not only to obtain the maximal number of cells, but also to reduce general costs by minimizing manipulation time, culture time and consumables spent. This can be achieved by increasing surface area available, with hollow fibers or microcarriers, and may have as a consequence to decrease the culture medium used per cell.

Another strategy is to increase the number of EVs secreted per cell. Indeed, if most (if not all) cells constitutivly release EVs, this process can be enhanced by stimulating them through serum starvation, hypoxia, or physical and chemical stresses ${ }^{38-41}$. On the other hand, large amounts of EV-like particles per cell can also be obtained by disruption of the cellular membrane. These approaches may produce vesicles, or vesicle-like particles, with other phenotypes than the ones of spontaneously produced $\mathrm{EVs}^{42,43}$.

Ultimately, EV final yield, nature and purity also results from the purification and enrichment strategies employed. To date, ultracentrifugation remains the gold standard to concentrate $\mathrm{EVs}^{44}$ for research purposes, despite a poor scalability and low recovery rate. Size-based isolation and enrichment techniques are thus rising, including size exclusion chromatography (SEC) or flow field fractionation (FFF). While density gradient ultracentrifugation is still the method of choice to purify EVs from soluble components, some researchers also developed affinity-based purification techniques, yet introducing issues regarding specificity and ubiquity of EV markers ${ }^{45}$. Other methods have been studied for the isolation of EVs, among which polymer precipitation or ion exchange chromatography, as reviewed elsewhere ${ }^{46-48}$. Finally, to translate to large-scale EV manufacturing, chromatography and ultrafiltration have been used for some time in order to concentrate and purify bio particles ${ }^{26}$ (e.g. viral particles, small proteins and antibodies), and are beginning to be implemented for $\mathrm{EVs}^{49,50}$.Considering the difficulty of isolating and characterizing $\mathrm{EVs}$, another strategy would be to prioritize therapeutic efficacy over purity ${ }^{51}$, manufacturing a secretomebased product or an EV-enriched secretome product, also aknowledging that bioactivity may also be due to soluble factors co-isolated with $\mathrm{EVs}^{52}$. .

Overall, EV manufacturing is a process which encompasses a considerable number of input parameters, each of them possibly generating an impact on the final product, either on its physical and chemical properties (size, number, zeta potential...), its biological content (proteins, RNAs, lipids, metabolites...), purity, stability or on its therapeutic potency. Indeed, what is often noted for any change in the upstream process of EV manufacturing is the largely unknown potential effects on the nature of the $\mathrm{EVs}^{53}$. Thus, a major challenge is to characterize the effect of the variation of these parameters on the final product identity and therapeutic activity. Yet, the lack of standardization of characterization and isolation methods impedes the comparison between studies, making it difficult to assess if differences are due to manufacturing strategies or to characterization techniques.

Additionally, regulations require the choice of GMP-compliant raw materials (xeno-free culture media, cells...), storage and administration strategies. GMP EV manufacturing processes should follow guidelines from the International Council for Harmonization of 


\section{SCALE-OUT}

EVs are secreted in the conditioned media

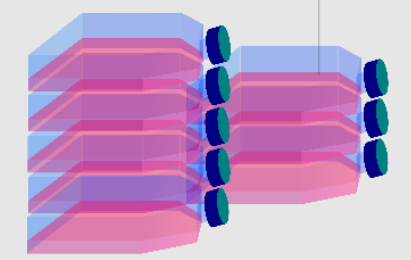

2D flasks

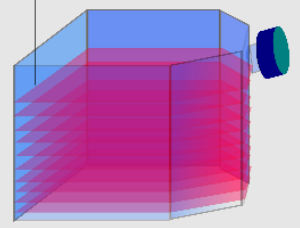

Hyperflasks

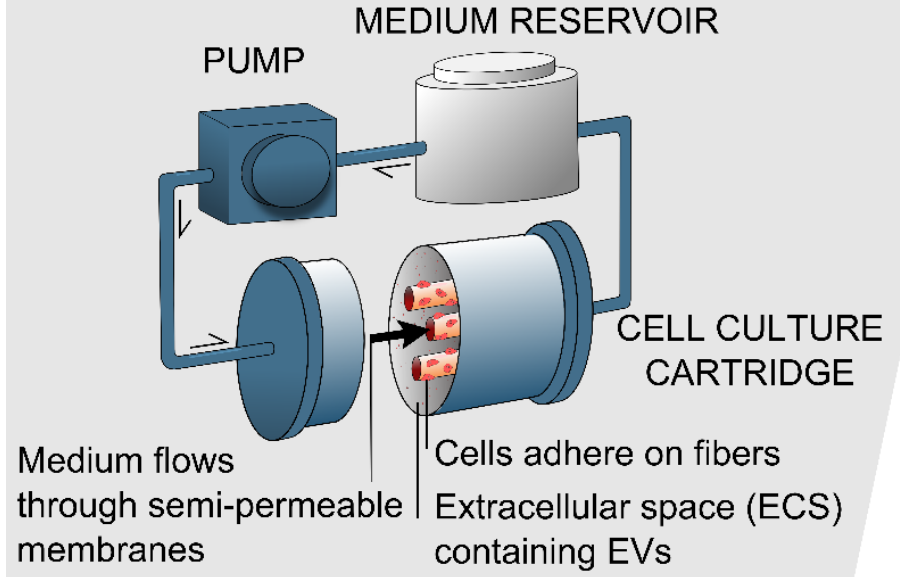

Hollow fiber bioreactor

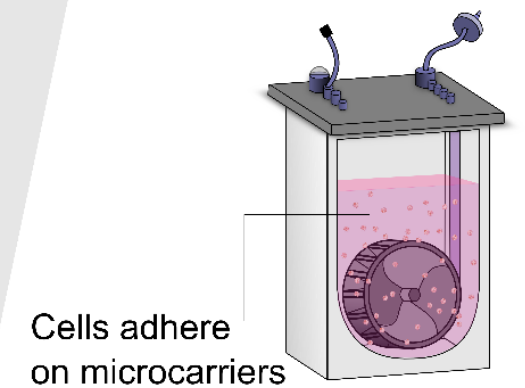

Vertical wheel $^{\mathrm{TM}}$ bioreactor

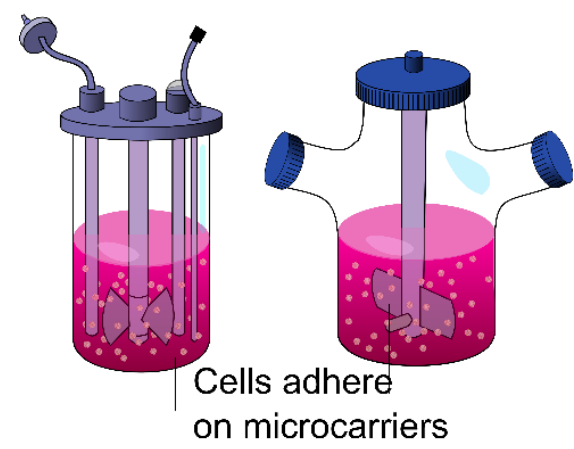

Stirred-tank bioreactor
Medium compartment

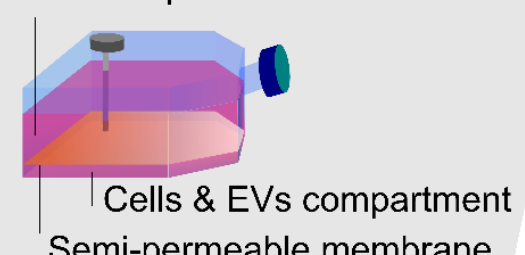

Integra CELLine

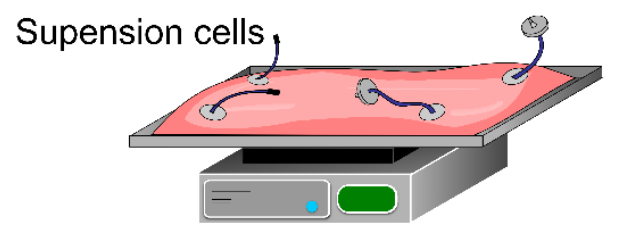

WAVE bioreactor

Figure 1 : Cellular platforms : principles of the different methods of cell expansion

Technical Requirements for Pharmaceuticals for Human Use (ICH), more specifically the Common Technical Document (CTD) for the registration of pharmaceuticals (available online : http://www.ich.org/products/guidelines). This document covers the quality, safety, and efficacy of pharmaceuticals manufacturing, addressing the topics of producer cells, raw materials, manufacturing and quality control. These recommendations are discussed more in depth in other papers, among which in a position paper on regulatory concerns published in this issue.

Finally, many companies and laboratories develop EV engineering strategies, optimizing loading and targeted delivery of EVs. While this is also a major stake in this 
field, it will not be detailed in the present paper which focuses on comparison between recent technologies for EV large-scale production, more specifically the scale-up of cell culture and the improvement of EV yield per cell.

\section{Optimized cellular culture: scaling out versus scaling up}

Most strategies to expand cells in vitro with minimal costs rely on the increase of surface area while minimizing the volume of culture media per cell. This induces the concentration of EVs in conditioned media and thus shortens the isolation process. Different platforms used for cell expansion and EV production are summarized in Table 1. In the cases where cell number was not reported at the end of the expansion phase, an estimated maximal cell number was indicated according to the literature ${ }^{54-56}$ or technical sheets obtained from the manufacturer's website.

\subsection{Scale-out}

The scale-out of the culture system consists in the optimization of the cell culture on a platform of limited size or scalability, but which can be parallelized to further expand the process. For instance, the use of the "flask" bioreactor Integra CELLine was proposed in $2008^{57}$. In this set-up, the cells are separated from the culture media by a $10 \mathrm{kDa}$ molecular weight cut off (MWCO) membrane, allowing the nutrients to be exchanged but not the larger molecules. EVs, which are produced in the cell compartment, are thus concentrated in a very small volume. In average, $180 \mathrm{~mL}$ of conditioned media, pooled from several harvests, yielded $1.5 \mathrm{mg}$ of proteins quantified by bicinchoninic assay (BCA) after sucrose gradient ultracentrifugation. The most common CELLine bioreactor can hold $1 \mathrm{~L}$ of media and $15 \mathrm{~mL}$ for the cell compartment, allowing a concentration of cells up to $1 \mathrm{E} 7-1 \mathrm{E} 8 \mathrm{cells} / \mathrm{mL}$. This technology has been used by Jeppesen et al. to produce large quantities of EVs from cancerous bladder cells for proteomics analysis ${ }^{58}$. Although this platform has been adapted to adherent cell lines, the maintenance of cells over extended period of times at high densities makes it not appropriate for stromal cells and this may explain why its use with MSC is not recommended by the supplier.

EV production in hyperflasks has also been recently reported by Madel et al..$^{59}$, in which between $1.2 \mathrm{E} 11$ and 3.8E11 particles (measured by Nanoparticle Tracking Analysis, "NTA") were obtained by precipitation and ultracentrifugation (UC). These EVs were produced from 4E7 bone marrow derived MSC (BM-MSC) cultivated in 4-layer flask Cell Factory ${ }^{\mathrm{TM}}$ (Nunc ${ }^{\mathrm{TM}}$ Thermofisher ${ }^{\mathrm{TM}}$ ) and in media supplemented with human platelet lysate not depleted of EVs. According to the manufacturer, the volume per hyperflask would be between $600 \mathrm{~mL}$ and $800 \mathrm{~mL}$, for a surface area of $2,528 \mathrm{~cm}^{2}$, which means there is no real economy in media required compared to 2D flasks, just a reduction of manual operations during cell culture and media harvest. Andriolo et al. ${ }^{60}$ obtained in average $3 \mathrm{E} 13$ particles from cardiac progenitor cells (CPC) cultivated for 14 days without serum in 16 hyperFLASKS $\circledast$ (Corning ${ }^{\circledR}$ ) each containing $500 \mathrm{~mL}$ media and $1,720 \mathrm{~cm}^{2}$ surface area. This work also evidences the feasibility of isolating EVs from a large volume of conditioned media $(8 \mathrm{~L})$ by filtration and tangential filtration.

One of the method of choice for scalable EV production is spontaneous release of EVs in hollow fiber bioreactor. Developed by FiberCell Systems and by Terumo (Quantum bioreactor), these bioreactors are perfusion bioreactors in which cells are grown on the 
surface of semi-permeable fibers through which the supplemented media flows. EVs released by cells accumulate in the media external to the fibers (termed extracellular space "ECS"), usually serum-free, which can easily be harvested every 4 to 14 days. Five hundred million adipose derived stromal cells (ASC) seeded in a C2011 (4,000 $\mathrm{cm}^{2}$ surface area, 20kDa MWCO) yielded between $1 \mathrm{E} 12$ and 3E12 particles in 4 to 7 weeks, corresponding to $12-14 \mathrm{mg}$ of proteins. One harvest of conditioned ECS consists in $40 \mathrm{~mL}$ with about $50 \mu \mathrm{g} / \mathrm{mL}$ of proteins ${ }^{61}$. However, it was observed that after 6 weeks of culture, ASC formed embryoids in the bioreactor, raising the question of the differentiation state of cells after several months of culture. In 2016, Watson et al. ${ }^{62}$ reported the utilization of the same cartridge to produce EVs from human embryonic kidney 293 cells (HEK293) expressing high levels of interleukin 15 in heterodimeric form (hetlL-15), obtaining similar yields. Interestingly, when using the particle over protein ratio and the protein concentration measured in the supernatant, and according to the estimated number of cells in the cartridge in order to calculate the total number of particles produced from one harvest $(20 \mathrm{~mL})$, one finds a 1,200 particle/cell yield in 48 to $72 \mathrm{~h}$, while it was in the 7,500 particle/cell range for T-flask culture in $48 \mathrm{~h}$. Our hypothesis would be that, as Patel et al ${ }^{63}$ described, the higher density of cells on the fibers leads to lower EV yield per cell. Even then, the specific set-up allowing cells to access nutrients through the semi-permeable fibers permits to have continuous culture and production of EVs over several weeks, which adds up to a large amount of EVs. To boost even more production output, collection frequency could also be optimized, as it has an effect on final EV yield ${ }^{63}$. Importantly, ratios of particles over proteins obtained from hollow-fiber EV production are repeatedly higher than for classic 2D culture. It is often regarded as a purity assessment, however it may also be linked to the overall protein content of EVs, which seems here to be reduced.

Nonetheless, Yan et al. ${ }^{64}$ showed that EVs from umbilical cord derived MSC (UC-MSC) produced in hollow fiber bioreactor had an improved osteochondral regeneration activity than 2D-EVs. Indeed, it increased proliferation of chondrocytes and promoted more effectively their migration than $2 \mathrm{D}-\mathrm{EV}$ s in vitro, and had a superior repair activity on cartilage defects in vivo. While this may not be true for all therapeutic applications, it indicates that hollow fiber EVs can be equally, if not more, potent than 2D-EVs. Moreover, the hollow fiber platform offers the possibility to engineer EVs, as was demonstrated by the large-scale production of EVs enriched with mir202 and mir-133a by overexpressing these miRNA in mother cells ${ }^{65}$. Finally, combining the hollow fiber technology and TFF or SEC enables the production and enrichment or purification of clinical grade EVs at moderately large scales ${ }^{35}$. Currently, Fibercell cartridges can contain up to $1.2 \mathrm{~m}^{2}$ of surface area available for cell culture ${ }^{66}$ [fibercellsystems.com], corresponding up to $5 \mathrm{E} 10$ cells per cartridge, depending on the cells. Mendt et al..$^{19}$ reported the use of the Quantum Bioreactor (Terumo) containing 11,500 hollow fibers with a surface area of $2.1 \mathrm{~m}^{2}$ for BM-MSC, seeded with 20 million cells, and it yielded about $1 \mathrm{E} 13$ vesicles in 12 days after 9 days of expansion. These quantities are already considerable and among the highest reported to this day, yet this technology would still need to be parallelized in order to deliver treatment to hundreds/thousands of patients, in Phase III /Phase IV trials, which will require, as was already mentioned, rigorous quality control checks to ensure batch to batch reproducibility. 

Inspired from the development of monoclonal antibody production ${ }^{37}$ or viral vectors ${ }^{26}$, the culture of cells in stirred tank bioreactors, with the eventual use of microcarriers for adherent cells, has been suggested as a scale-up strategy for EV production ${ }^{27}$. Recently, first results of yields obtained in these conditions have been published ${ }^{28,34,67}$. Human UC-MSC were cultured on Star-Plus Solohill® beads in a $250 \mathrm{~mL}$ spinner flask, and $\mathrm{EV}$ production was initiated after $48 \mathrm{~h}$ of culture in xeno-free StemPro ${ }^{\mathrm{TM}}$ medium from $4.6 \mathrm{E} 7 \mathrm{cells}^{34}$. EVs were isolated by UC or TFF and it was calculated that with TFF $1 \mathrm{E} 5$ particle/cell were obtained and 1.4E4 particle/cell with UC in 3D cultures, whereas it was 2E4 particle/cell and 7E2 particle/cell for TFF and UC respectively for 2D flasks. While it appears that 3D culture alone increases the number of particle/cell, the final yield is mostly increased by the use of TFF over UC. Furthermore, the authors evidenced that EVs produced by all four processes contained similar proteins, even though the particles over proteins ratio was decreased 2 to 4 fold with 3D culture compared to 2D. 3D EVs were also more efficient than 2D EVs at delivering silencing siRNA that had been loaded onto the EVs post production.

In an application note from Eppendorf, Escabar Irivico and Sha ${ }^{67}$ described the process by which they produced EVs from induced pluripotent stem cell derived MSC cultured on collagen coated microcarriers in a single use stirred tank bioreactor vessel, controlled in $\mathrm{pH}$, dissolved oxygen and temperature, seeded with 9E6 cells. They quantified EVs with the ExoELISA-ULTRA CD63 Kit (System Biosciences), reporting between 2.6E10 EVs at day 5 and 8.6E10 EVs at day 16.

On the other hand, de Almeida Fuzeta et al. ${ }^{28}$ proposed the Vertical-Wheel ${ }^{\mathrm{TM}}$ bioreactor technology as an alternative to the conventional spinner flask in order to mix more gently and homogeneously the cellular suspension. Their approach also consisted in demonstrating the feasibility of this technique as a scalable xeno-free microcarriers based system. They compared the EV yield measured by NTA between 2D and 3D conditions for three cell lines: BM-MSC, ASC and UC-MSC. Overall, it was observed that MSC produced around three times more particles per cell upon 3D condition, and as the ratio of media over surface area was decreased, the final concentration of EVs in conditioned media was multiplied by almost 6 . They obtained 2.8E11, 3.1E11 and 4.1E11 particles from approximately 25 million BM-MSC, ASC and UC-MSC respectively. No significant difference was found in the particle/protein ratio between 2D and 3D. As a proof of concept, this study was performed in a $100 \mathrm{~mL}$ bioreactor and isolation of EVs was performed with Total Isolation Kit (Invitrogen), but the isolation strategy will need to be revised for scale-up to a volume of 3 to $500 \mathrm{~L}$.

\subsection{Adaptation to suspension cells}

Diversifying the source of cells may be a promising approach to optimize EV yield with any technology. Notably, for drug delivery purposes, cells easier to cultivate have been investigated, such as THP- $1^{68}$ or U93769 suspension cell lines, for which the issue of scaling up cell culture becomes minimal. Indeed, similarly to bacteria or yeasts, suspension cell lines are easily cultured in stirred tank bioreactors that are the most straightforward for large-scale culture. Culturing $1000 \mathrm{~L}$ volume and over were already implemented in the early 2000 s for the production of monoclonal antibodies with the 
Table 1 : Medium to large scale cellular platforms

\begin{tabular}{|c|c|c|c|c|c|c|c|c|c|c|c|c|}
\hline $\begin{array}{l}\text { Type of } \\
\text { culture }\end{array}$ & Cells & $\begin{array}{l}\text { Surface } \\
\text { area }\left(\mathrm{cm}^{2}\right)\end{array}$ & $\begin{array}{l}\text { Seeding } \\
\text { cell } \\
\text { density }\end{array}$ & $\begin{array}{l}\text { Max } \\
\text { cells } \\
\text { growth }\end{array}$ & $\begin{array}{l}\text { Culture } \\
\text { time }\end{array}$ & $\begin{array}{l}\text { Working } \\
\text { volume }\end{array}$ & $\begin{array}{l}\text { Production } \\
\text { media }\end{array}$ & Harvests & $\begin{array}{l}\text { EV in } \\
\text { supernatant }\end{array}$ & $\begin{array}{l}\text { Isolation } \\
\text { method }\end{array}$ & $\begin{array}{l}\text { EV } \\
\text { isolated }\end{array}$ & \\
\hline $\begin{array}{l}\text { CELLine } \\
\text { bioreactor }\end{array}$ & $\begin{array}{l}\text { mesothelioma } \\
\text { cells } \\
\text { NKL cells }\end{array}$ & $\sim 300 \mathrm{~cm}^{2}$ & $30 \mathrm{E} 6 / 15 \mathrm{~mL}$ & $\begin{array}{l}\text { Estim. } \\
\text { 400E6 }\end{array}$ & $\begin{array}{l}>6 \\
\text { months }\end{array}$ & $\begin{array}{l}15 \mathrm{~mL} \text { cell } \\
\mathrm{CM} / 500 \mathrm{~mL} \\
\text { outer volume }\end{array}$ & $\begin{array}{l}\text { RPMI + } 10 \% \\
\text { FBS }\end{array}$ & $\begin{array}{l}15 \mathrm{~mL} \text { every } \\
4-7 \text { days }\end{array}$ & $\begin{array}{l}10.06 \mu \mathrm{g} / \mathrm{mL} \text { of } \\
\mathrm{CM} \\
6.76 \mu \mathrm{g} / \mathrm{mL} \text { of } \\
\mathrm{CM} \\
(\mathrm{BCA})\end{array}$ & $\begin{array}{ll}\text { UC } & + \\
\text { sucrose } & \\
\text { gradient } & \end{array}$ & $\begin{array}{lcc}1,5 & \mathrm{mg} & \text { for } \\
180 & \mathrm{~mL} & \text { of } \\
\mathrm{CM} & & \end{array}$ & 57 \\
\hline $\begin{array}{l}\text { Hyper- } \\
\text { flasks }\end{array}$ & $\begin{array}{l}\text { CPC } \\
\text { BM-MSC }\end{array}$ & $\begin{array}{l}16 \times 1,720 \mathrm{~cm}^{2} \\
=2.75 \mathrm{~m}^{2} \\
2,528 \mathrm{~cm}^{2} \text { per } \\
\text { flask }\end{array}$ & $3 \mathrm{E} 4 / \mathrm{cm}^{2}$ & $\begin{array}{l}\text { Estim. } \\
2.7 E 9 \\
\\
\text { Estim. } \\
1 \text { E8 per } \\
\text { flask }\end{array}$ & $>48 \mathrm{~h}$ & $\begin{array}{l}600-800 \mathrm{~mL} \\
\text { per flask }\end{array}$ & $\begin{array}{l}\text { Serum free } \\
\text { DMEM + 10\% } \\
\text { hPL }\end{array}$ & $\begin{array}{l}\text { After } 2 \text { weeks } \\
\text { Every } 48 \mathrm{~h} \\
\text { from } 50 \% \text { to } \\
80 \% \\
\text { confluence }\end{array}$ & - & $\begin{array}{l}\text { TFF } \\
\text { PEG } \\
\text { precipitation }\end{array}$ & $\begin{array}{l}\text { 3E13 part } \\
\text { (NTA) } \\
\\
2.4 \mathrm{E} 11 \text { part / } \\
40 \text { million } \\
\text { cells } \\
\text { (NTA) } \\
\end{array}$ & 59 \\
\hline $\begin{array}{l}\text { Hollow } \\
\text { fiber }\end{array}$ & ASC & $4,000 \mathrm{~cm}^{2}$ & $\begin{array}{l}1.25 \mathrm{E} 5 \\
\text { cells/cm² }\end{array}$ & $\begin{array}{l}\text { Estim. } \\
1-2 E 9\end{array}$ & $\begin{array}{l}4-8 \\
\text { weeks }\end{array}$ & $\begin{array}{l}20-40 \mathrm{~mL} \\
20 \mathrm{~mL}\end{array}$ & Serum free & $\begin{array}{l}6-7 \text { harvests } \\
\text { (every } 4 \text { to } 7 \\
\text { days) }\end{array}$ & $\mathrm{x}$ & UC & $\begin{array}{l}2.1 \mathrm{E} 12 \text { part } \\
\text { (NTA) }\end{array}$ & 61 \\
\hline $\begin{array}{l}\text { C2011 } \\
20 \mathrm{kDa} \\
\text { MWCO }\end{array}$ & HEK293 & & $\begin{array}{l}7,5 \mathrm{E} 4 \\
\text { cells/cm² }\end{array}$ & & $\begin{array}{l}16 \text { weeks } \\
21 \text { days }\end{array}$ & $250 \mathrm{~mL}$ & Serum free & $\begin{array}{l}3 \text { harvests / } \\
\text { week }\end{array}$ & 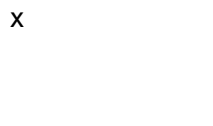 & $\begin{array}{l}\text { Filtration } \\
\text { UC }\end{array}$ & $\begin{array}{l}1.2 \mathrm{E} 12 \text { part } \\
\text { or } 1.1 \mathrm{mg} \text { per } \\
\text { harvest } \\
\text { (NTA) }\end{array}$ & 62 \\
\hline $\begin{array}{l}\text { Quantum } \\
\text { bioreactor }\end{array}$ & BM-MSC & $\begin{array}{l}2.1 \mathrm{~m}^{2}(11,500 \\
\mathrm{HF})\end{array}$ & $\begin{array}{l}\sim 1000 \\
\text { cells } / \mathrm{cm}^{2}\end{array}$ & $\begin{array}{l}\text { Estim. } \\
\text { 7E8 cells }\end{array}$ & & & Platelet free & $\begin{array}{l}6 \text { harvests } \\
\text { (every } 48 \mathrm{~h} \text { ) }\end{array}$ & $\begin{array}{l}9.8-15.6 \text { E12 } \\
\text { part } \\
\text { (NTA) }\end{array}$ & UC & $x$ & 29 \\
\hline $\begin{array}{l}\text { Spinner } \\
\text { flasks }\end{array}$ & UC-MSC & $\begin{array}{l}1,150 \mathrm{~cm}^{2}(3.2 \\
\mathrm{g} \text { of beads) }\end{array}$ & $\begin{array}{l}3,000 \\
\text { cells } / \mathrm{cm}^{2}\end{array}$ & $\begin{array}{l}4.6 \mathrm{E} 7 \\
\text { cells }\end{array}$ & $\begin{array}{l}48 \mathrm{~h}+ \\
4 \times 48 \mathrm{~h}\end{array}$ & $250 \mathrm{~mL}$ & Serum free & $\begin{array}{l}4 \quad \text { harvests } \\
\text { (every } 48 \mathrm{~h})\end{array}$ & - & TFF & $\begin{array}{l}4.6 E 12 \text { part } \\
\text { (NTA) }\end{array}$ & 34 \\
\hline $\begin{array}{l}\text { Vertical } \\
\text { wheel }\end{array}$ & $\begin{array}{l}\text { BM-MSC } \\
\text { ASC } \\
\text { UC-MSC }\end{array}$ & $720 \mathrm{~cm}^{2}(2 \mathrm{~g})$ & $\begin{array}{l}7,000 \\
\text { cells } / \mathrm{cm}^{2}\end{array}$ & $\begin{array}{l}12-53 \mathrm{E} 6 \\
\text { cells } \\
29 \mathrm{E} 6 \\
\text { cells } \\
\\
20 \mathrm{E} 6 \\
\text { cells } \\
\end{array}$ & $\begin{array}{l}7-11 \\
\text { days } \\
7 \text { days } \\
10 \text { days }\end{array}$ & $60 \mathrm{~mL}$ & Serum free & 1 after $48 \mathrm{~h}$ & $\begin{array}{l}\text { 2.8E11 part } \\
3.1 \mathrm{E} 11 \text { part } \\
\text { 4.1E11 part } \\
\text { (NTA) }\end{array}$ & $\begin{array}{l}\text { Total } \\
\text { Isolation kit }\end{array}$ & - & 28 \\
\hline
\end{tabular}


Chinese Hamster Ovarian ( $\mathrm{CHO}$ ) cell line which has been engineered for suspension culture $^{37}$. This strategy to modify the cell line to make the suspension culture possible can also be implemented for EV production ${ }^{70}$. However, as culture in spinner flasks has been shown to inhibit the expansion of primary $T$ lymphocyte ${ }^{71}$, it may also affect the nature of EV produced. On the contrary, regulatory $T$ cells yield was increased almost 20-fold in a hollow fiber Quantum reactor in the presence of a soluble activator complex compared to 2D flasks. Ultimately, it goes back to the lack of standardized characterization methods for potency, because despite the fact that $\mathrm{EV}$ complex nature was shown to be affected by changes in culture conditions ${ }^{72}$, the current challenge is to demonstrate the potency of such EVs.

Finally, blood-derived cells such as red blood cells (RBC) or peripheral blood mononuclear cells (PBMC) have also been regarded as an interesting source of $\mathrm{EVs}^{73-}$ 75 for their relative ease of manufacture in very large quantities. Specifically, RBC do not need to be cultured and can be stored at $4^{\circ} \mathrm{C}$ up to 120 days, which means that cell expansion platforms are not needed.

Considering that even among MSCs, some cells produce more than others ${ }^{34}$, systematic preliminary studies to select parental cells based on their intrinsic EV secretion rate and the therapeutic goals expected would maximize EV final amount.

\section{Stimulating cells to increase EV yield}

\subsection{Physical \& chemical stimulation}

Another strategy to scale up EV production is to increase the yield of EV produced per each single cell. The final EV yield is not only the result of release but it also involves the recapture by cells. It is then difficult to assess if one process affects the former or the later action. Anyway, several treatments have been shown to increase the number of EVs compared to spontaneous release from equivalent number of cells ${ }^{40}$. These are summarized in Table 2, in which yield is reported as an enhancement factor compared to control, consisting in treating the same number of cells for the same duration in the indicated production media.

The most widely used stimulation is certainly serum deprivation ${ }^{76}$, which not only was reported to boost $E V$ yield ${ }^{42}$ but also brings the advantage of avoiding $E V$ contaminants brought by the serum even when depleted of particles. As the most common starting material, EV produced in serum-free media are often used as a reference to compare yields obtained after other types of stimulation (see Table 2). Other physico-chemical stresses improve the $\mathrm{EV}$ production, such as hypoxia ${ }^{39,77,78}$, low $\mathrm{pH}^{79,80}$, heat shock ${ }^{81}$ or ultrasounds ${ }^{82}$. In the later, Zhao et al. ${ }^{82}$ have evidenced that exposition of ovarian cancer cells to ultrasound for 60 to 90 minutes multiplied the protein yield of vesicles preparation by two. Increased vesiculation from endothelial cells was also observed with transmission electronic microscopy (TEM) after low level irradiation $\left(80 \mathrm{~J} / \mathrm{cm}^{2}\right)$ using diode laser at a wavelength of $675 \mathrm{~nm}$ while investigating the mechanisms behind angiogenesis modulation after photodynamic therapy ${ }^{83}$. Particle concentration and protein amount were not indicated but the level of CD63 in supernatant was measured at $0.9 \mathrm{ng} / \mathrm{mL}$ compared to $0.5 \mathrm{ng} / \mathrm{mL}$ in the control. 
Additionally, EV yield can be enhanced by the use of chemical agents. For example, $100 \mathrm{mM}$ ethanol conditioning for $48 \mathrm{~h}$ multiplied particle concentration measured by NTA by a factor 10 for primary hepatocytes ${ }^{41}$ and a factor 4 for primary monocytes ${ }^{68}$. Other chemical stimulations include the use of anti-inflammatory drugs such as acetylsalicylic acid, celecoxib and chloroquine ${ }^{84}$. Similarly, activated neutrophils, incubated 20 min with TNF- $\alpha$, IL8 or LBT4, produced between two and three times more EVs than control cells ${ }^{30}$, characterized by imaging flow cytometry. In the same article ${ }^{30}$, Headland et al. also reported that cytochalasin $\mathrm{D}$, an actin polymerization inhibitor, increased twice the number of EVs measured.

Finally, exposition of cells to several types of exogenous particles have also been reported to increase EV secretion. Internalization of positively charged iron oxide nanoparticles encapsulated in PLGA-PEI polymer by MSCs increased secretion of extracellular vesicles, which appeared to be linked to increased autophagosome formation ${ }^{85}$. In Emam et al. ${ }^{86}$, four cancerous cell lines were incubated for $48 \mathrm{~h}$ with different concentration of neutral, cationic-bare or PEGylated liposomes solutions. Neutral (NL) and cationic bare liposomes (CL) enhanced protein concentration in isolated EVs for all four cell lines, by a factor of about 2 for NL and $\geq 3$ for CL at $2 \mathrm{mM}$. This approach may however require more purification steps, and the possible underlying mechanisms remain at the moment unknown.

Another physically-derived strategy to trigger EV release is to rely on mechanical stress for the stimulation. In 2017, our team demonstrated the feasibility of EV release from endothelial cells induced by a laminar flow in a microfluidic chip ${ }^{31}$. As this fluidics-based work is not easily scalable, we next developed shear stress induced vesiculation in a turbulent flow in spinner flasks by increasing the stirring speed, combining a largescale culture platform and a 10-fold increase of particle/cell yield compared to classic starvation ${ }^{89,90}$ (WO2019002608). Typically, about 1E13 particles were obtained from 3.9E8 murine MSCs cultured on Cytodex 1 beads in a $1 \mathrm{~L}$ spinner flask after $4 \mathrm{~h}$ of turbulence stimulation ${ }^{91,92}$. Administered in a thermoresponsive gel, these EVs were shown to decrease fistula output and external orifice diameter in a rat model of colocutaneous post-surgical fistula ${ }^{91}$. These $\mathrm{EVs}$ were also loaded with meta(tetrahydroxyphenyl)chlorin (mTHPC), a photosensitizer used for photodynamic therapy and injected intraperitoneally in mice with colorectal and ovarian carcinomatosis, showing enhanced tumor specificity ${ }^{92}$. After laser irradiation, survival was improved compared to free drug but also to the liposomal formulation of mTHPC. Patel et al. ${ }^{88}$ also used shear stress to stimulate EV production in a 3D printed perfusion bioreactor, which they infused with a $4 \mathrm{~mL} / \mathrm{min}$ EV-depleted media flow (corresponding to shear stresses between 1.5E-2 dyn/cm ${ }^{2}$ and $1.3 \mathrm{dyn} / \mathrm{cm}^{2}$ ), and obtained a 20-fold increase in particles after isolation from human dermal microvascular endothelial cells (HDMEC) compared to the classic flask culture, going from 4E9 particles to $8.7 \mathrm{E} 10$ particles in $48 \mathrm{~h}$ from 1 million cells. ${ }^{88}$ Interestingly, they also stimulated the endothelial cells with $100 \mathrm{mM}$ ethanol and compared the results to the non-stimulated samples. The number of particles produced in the presence of ethanol was similar, but the pro-vascularization activity of EVs produced with ethanol conditioning was superior. Although this study was not yet adapted to large scales, it evidenced the feasibility and potential of perfusion bioreactor for production of therapeutic EVs. 
Table 2: Recapitulative table of stimulation methods to increase EV produced per cell

\begin{tabular}{|c|c|c|c|c|c|c|c|c|}
\hline \multicolumn{2}{|l|}{ Stimulation } & Cells & $\begin{array}{l}\text { Treatment } \\
\text { duration }\end{array}$ & $\begin{array}{l}\text { Production } \\
\text { media }\end{array}$ & $\begin{array}{l}\text { Isolation } \\
\text { method }\end{array}$ & Measurement method & $\begin{array}{l}\text { Enhancement } \\
\text { factor } \\
\text { (stim/control) }\end{array}$ & Ref \\
\hline \multirow[t]{3}{*}{ Hypoxia } & $1 \% \mathrm{O}_{2}$ & \multirow[t]{2}{*}{ MCF7 } & $48 \mathrm{~h}$ & \multirow[t]{2}{*}{ EV-depleted } & \multirow[t]{2}{*}{ UC } & \multirow{2}{*}{$\begin{array}{l}\text { Particles in isolated EVs } \\
\text { (NTA) }\end{array}$} & 1.44 & \multirow[t]{2}{*}{39} \\
\hline & $0.1 \% \mathrm{O}_{2}$ & & $24 \mathrm{~h}$ & & & & 1.77 & \\
\hline & $0.5 \% \mathrm{O}_{2}$ & mMSC & $24 h$ & Serum-free & $x$ & $\begin{array}{l}\text { Particles in supernatant } \\
\text { (NTA) }\end{array}$ & 1.2 & 77 \\
\hline \multirow[t]{2}{*}{ Low pH } & $\mathrm{pH} 4$ & HEK293 & $72 \mathrm{~h}$ & EV-depleted & Exoquick & $\begin{array}{l}\text { Extracted proteins in } \\
\text { supernatant }(B C A)\end{array}$ & 5 & 80 \\
\hline & $\mathrm{pH} 6$ & $\begin{array}{l}\text { Melanoma } \\
\text { cells }\end{array}$ & $\begin{array}{l}48 \mathrm{~h} / 72 \mathrm{~h} / \\
96 \mathrm{~h}\end{array}$ & EV-depleted & $\begin{array}{l}\text { UC + sucrose } \\
\text { gradient }\end{array}$ & $\begin{array}{l}\text { Proteins in isolated EVs } \\
\text { (BCA) }\end{array}$ & $2 / 3 / 7.5$ & 79 \\
\hline \multicolumn{2}{|c|}{ Glucose deprivation } & $\mathrm{H} 9 \mathrm{C} 2$ & $48 \mathrm{~h}$ & Serum free & UC & $\begin{array}{l}\text { CD9/ CD81/ CD63 band } \\
\text { intensity in WB }\end{array}$ & $\sim 3$ & 87 \\
\hline Heat shock & $42^{\circ} \mathrm{C} 10 \mathrm{~min}-1 \mathrm{~h}$ & 3LL & $4 \mathrm{~h}$ & Serum-free & UC & Proteins in isolated EVs & 2.3 & 81 \\
\hline Shear stress & $\begin{array}{l}\text { Medium flowing } \\
\text { in } 3 D \text { printed } \\
\text { bioreactor }\end{array}$ & HDMECs & $72 \mathrm{~h}$ & EV-depleted & $\begin{array}{l}\mathrm{UC}+\text { spin } \\
\text { column }\end{array}$ & $\begin{array}{l}\text { Particles in isolated EVs } \\
\text { (NTA) }\end{array}$ & 22 & 88 \\
\hline \multirow[t]{2}{*}{ Ethanol } & $100 \mathrm{mM}$ & Hepatocytes & $48 \mathrm{~h}, 72 \mathrm{~h}$ & EV-depleted & Exoquick & $\begin{array}{l}\text { Particles in supernatant } \\
\text { (NTA) }\end{array}$ & $7 / 5$ & 41 \\
\hline & $50 \mathrm{mM}, 100 \mathrm{mM}$ & monocytes & $48 \mathrm{~h}$ & EV-depleted & Exoquick & $\begin{array}{l}\text { Particles in supernatant } \\
\text { (NTA) }\end{array}$ & 4 & 68 \\
\hline \multirow[t]{3}{*}{ Cytokines } & TNF- $\alpha$ (50ng/mL) & \multirow[t]{5}{*}{ Neutrophils } & \multirow[t]{5}{*}{$20 \mathrm{~min}$} & \multirow[t]{5}{*}{ PBS } & \multirow[t]{5}{*}{$x$} & \multirow{5}{*}{$\begin{array}{l}\text { Particles in supernatant } \\
\text { (Imagestream) }\end{array}$} & 3.5 & \multirow[t]{5}{*}{30} \\
\hline & IL8 (50ng/mL) & & & & & & 3.25 & \\
\hline & LTB4 (10nM) & & & & & & 3 & \\
\hline \multirow{2}{*}{$\begin{array}{l}\text { Cytoskeleton } \\
\text { disruption }\end{array}$} & Cytochalasin D & & & & & & 3.4 & \\
\hline & ML7 & & & & & & 2.8 & \\
\hline \multirow{3}{*}{$\begin{array}{l}\text { Anti- } \\
\text { inflammatory } \\
\text { drug }\end{array}$} & Aspirin $2.5 \mathrm{mM}$ & \multirow[t]{3}{*}{ MDA-MB-231 } & \multirow[t]{3}{*}{$24 \mathrm{~h}$} & \multirow[t]{3}{*}{ Serum free } & \multirow[t]{3}{*}{$x$} & \multirow{3}{*}{$\begin{array}{l}\text { Particles in supernatant } \\
\text { (NTA) }\end{array}$} & 5.6 & \multirow[t]{3}{*}{84} \\
\hline & Celecoxib $20 \mu \mathrm{M}$ & & & & & & 23.7 & \\
\hline & $\begin{array}{l}\text { Chloroquine } \\
20 \mu \mathrm{M}\end{array}$ & & & & & & 10.2 & \\
\hline $\begin{array}{l}\text { Low intensity } \\
\text { ultrasound }\end{array}$ & $0.5 \mathrm{~W} / \mathrm{cm}^{2} 1 \mathrm{~h}$ & A2780 & $6 h$ & Serum-free & Exoquick & Proteins in isolated EVs & 1.75 & 82 \\
\hline Laser irradiation & $80 \mathrm{~J} / \mathrm{cm}^{2}$ & HUVEC & $48 \mathrm{~h}$ & EV-depleted & $\mathrm{X}$ & CD63 in supernatant & 1.8 & 83 \\
\hline \multicolumn{2}{|c|}{$\begin{array}{l}\text { Incubation with SPIOs encapsulated } \\
\text { in PLGA-PEI polymer }\end{array}$} & hMSC & $24 h$ & Complete & Exoquick & $\begin{array}{l}\text { CD9/ CD81/ CD63 band } \\
\text { intensity in WB }\end{array}$ & $\sim 2.5$ & 85 \\
\hline \multirow{2}{*}{$\begin{array}{l}\text { Incubation with } \\
\text { liposomes }\end{array}$} & Neutral & \multirow{2}{*}{$\begin{array}{l}\text { C26 / B13BL6 } \\
\text { /MKL45/DLD1 }\end{array}$} & \multirow[t]{2}{*}{$48 \mathrm{~h}$} & \multirow[t]{2}{*}{ EV-depleted } & \multirow[t]{2}{*}{ Exoquick } & \multirow[t]{2}{*}{ Proteins in isolated EVs } & $\sim 2.5$ & \multirow[t]{2}{*}{86} \\
\hline & Cationic & & & & & & $\sim 3.5$ & \\
\hline
\end{tabular}


It is to be noted that different stresses may have different effects depending on the type of cells. For example, ethanol conditioning induced increased EV release in monocytes and hepatocytes whereas it did not change EV yield for endothelial cells, although the set-ups were very different. The rationale for the stimulation of the cells usually comes from physiological or pathological conditions, such as the use of shear stress on endothelial cells ${ }^{93}$, or the treatment of hepatocytes with ethanol to mimic binge drinking ${ }^{41}$. Notably, stress-mediated EV production have often been reported on cancerous cells as a proof-of-concept, because they are often easier to cultivate than primary cells or stem cells. Besides, it was also shown that EV release from cancer cells can be triggered in vitro and in vivo by the cancer therapy itself, such as chemotherapy ${ }^{94}$ or photodynamic therapy ${ }^{95}$. Interestingly, increased vesiculation in response to stress was also demonstrated in Gram negative bacteria, as a defensive mechanism to improve survival in a hostile environment ${ }^{96}$. For example, Staphylococcus aureus EV production, quantified by protein yield, was increased approximately three times by low temperature $\left(30^{\circ} \mathrm{C}\right)$, oxidative stress, in iron-depleted media, or at sub-inhibitory concentration of antibiotic, which are stresses that may occur as the pathogen is infecting a new host ${ }^{97}$.

Although EVs produced by stimulation are often reported to have similar physical characteristics (size, zeta potential, topology observed by TEM) compared to spontaneously secreted EVs, their protein and RNA contents may differ ${ }^{42,43}$. Nevertheless, the main stake of manufacturing $E V s$ is to produce therapeutically potent vesicles, which is why most works report the efficacy of their stress-mediated produced EVs in potency assays, that we will describe later.

In the optics to potentiate the EVs produced, some strategies have been adopted which may be contrary to the dogma that cells must remain alive during EV production. Indeed, while some authors warned that apoptotic bodies contamination may hinder therapeutic effect of EV preparations ${ }^{53}$, HJ Ankersmit's team has shown that the secretome of apoptotic peripheral blood mononuclear cells (PBMC) are efficient for skin regeneration and angiogenesis ${ }^{98}$, and also has immunomodulatory capabilities ${ }^{99}$, which makes this EV-containing product a very promising treatment, with possibility of scale-up as the source cells are readily available in large quantities. Although not fully elucidated, inducing apoptosis in blood cells has already been used in clinical settings for decades to treat inflammatory diseases when using the extracorporeal photopheresis method ${ }^{100}$.

\subsection{EV-like particles}

To address the issue of production and reproducibility, some works reported other strategies to create EV-like particles by completely disrupting the cell membrane integrity, releasing self-assembled particles with a yield up to 100 times superior to EV, which was recently reviewed in Lu et Huang ${ }^{101}$. Yet, direct comparison between yields is not as straightforward as for chemical and physical stimulation because EV are secreted in culture media and often purified in a different way than EV-like particles, that are produced directly in PBS. Protein and particle amounts measured for production techniques of EV-like particles, all using PBS as production media, are reported in Table 3. 
Table 3: High-yield production of EV-like particles

\begin{tabular}{|c|c|c|c|c|c|c|c|}
\hline Treatment & Cells & $\mathrm{Nb}$ of cells & Volume & $\begin{array}{l}\text { Isolation } \\
\text { method }\end{array}$ & $\begin{array}{l}\text { Total } \\
\text { protein }\end{array}$ & $\begin{array}{l}\text { Total } \\
\text { particle }\end{array}$ & Ref \\
\hline \multirow[t]{5}{*}{$\begin{array}{l}\text { Extrusion through } \\
10-5-1 \mu \mathrm{m} \text { filters }\end{array}$} & Murine ESC & 1E8 & $1 \mathrm{~mL}$ & $\begin{array}{l}\text { Density } \\
\text { gradient }\end{array}$ & $952 \mu \mathrm{g}$ & $X$ & 32 \\
\hline & U937 & $1 \mathrm{E} 7$ & $1 \mathrm{~mL}$ & $\begin{array}{l}\text { Density } \\
\text { gradient }\end{array}$ & $203 \mu \mathrm{g}$ & $2.1 \mathrm{E} 11$ & 69 \\
\hline & MCF-10A & $1 \mathrm{E} 7$ & $1 \mathrm{~mL}$ & $\begin{array}{l}\text { Density } \\
\text { gradient }\end{array}$ & $379 \mu \mathrm{g}$ & $3 \mathrm{E} 11$ & 105 \\
\hline & BM-MSC & $4 \mathrm{E} 6 / \mathrm{mL}$ & $X$ & $\begin{array}{l}\text { Density } \\
\text { gradient }\end{array}$ & $161 \mu \mathrm{g}$ & $5.18 \mathrm{E} 10$ & 102 \\
\hline & $\begin{array}{l}\text { mouse } \\
\text { hepatocytes }\end{array}$ & $5 \mathrm{E} 6$ & $1 \mathrm{~mL}$ & $\begin{array}{l}\text { Density } \\
\text { gradient }\end{array}$ & $110 \mu \mathrm{g}$ & $x$ & 106 \\
\hline Spin cups & U937 & $2 \mathrm{E} 7$ & $1 \mathrm{~mL}$ & SEC & $540 \mu \mathrm{g}$ & $x$ & 104 \\
\hline $\begin{array}{l}\text { Microfluidic } \\
\text { channels }\end{array}$ & Murine ESC & 1.5E6 & $1 \mathrm{~mL}$ & $\begin{array}{l}\text { Density } \\
\text { gradient }\end{array}$ & $115 \mu \mathrm{g}$ & $x$ & 103 \\
\hline Slicing blades & Murine ESC & $1 \mathrm{E} 7$ & $1 \mathrm{~mL}$ & $\begin{array}{l}\text { SEC } \\
\text { Amicon }\end{array}+$ & $3.5 \mu \mathrm{g}$ & $1 \mathrm{E} 11$ & 33 \\
\hline $\begin{array}{l}\text { Hypotonic shock } \\
+ \\
\text { homogeneization } \\
+\quad \text { sonication } \\
\text { (Nanoghosts) }\end{array}$ & $\begin{array}{lr}\text { hMSC, rat } \\
\text { MSC } \\
\text { hSMC }\end{array}$ & $x$ & $x$ & UC & $x$ & $x$ & 107 \\
\hline $\begin{array}{l}2 \mathrm{mM} \text { PFA }+2 \mathrm{mM} \\
\text { DTT } 2 \mathrm{~h} \\
\text { (extracellular } \\
\text { blebs) }\end{array}$ & $\begin{array}{l}\text { Mouse } \\
\text { lymphoma } \\
\text { cells }\end{array}$ & 1E7cells/mL & $x$ & $\begin{array}{l}30 \text { Kda } \\
\text { centrifugal } \\
\text { tubes }\end{array}$ & $100 \mu \mathrm{g} / \mathrm{mL}$ & $x$ & 108 \\
\hline
\end{tabular}

The most common way to disrupt cells is by extrusion, which consists in sequential filtration through smaller and smaller pore size (from $10 \mu \mathrm{m}$ to $1 \mu \mathrm{m}$ ), and this has been done with suspension ${ }^{69}$ or adherent cells ${ }^{32,69,102}$ to form particles termed nanovesicles (NVs). Other studies have reported the use of microfluidic chips, in which cells are forced through channels smaller than their diameter ${ }^{103}$, or containing micro fabricated silicon nitride blades slicing the cell membrane ${ }^{33}$. All these processes can be seen as a trade-off between high yield, purity, production time and therapeutic potency. Indeed, cells can be highly concentrated within a small volume of particle-free PBS and thus will yield a considerable amount of self-assembled particles in a very short time as they are extruded, also releasing their intracellular content. Purification has then to be more thorough to separate contaminants from NVs, such as density gradient or SEC, but is usually easier to perform because of the smaller volumes. Goh et al ${ }^{104}$ advocated that the production time reduced from $48 \mathrm{~h}$ to $1 \mathrm{~h}$ combined to the use of affordable spin cups and a simple step of size exclusion chromatography (compared to differential ultracentrifugation to isolate the particles) render their technique a cost-effective method to produce EV-like particles at large scale.

NVs can be used as drug delivery vehicles which can encapsulate siRNA ${ }^{105}$ or chemotherapeutics, such as doxorubicin or paclitaxele9,102 and have also shown therapeutic potential in vivo for immunotherapy ${ }^{109,110}$ and liver regeneration ${ }^{106}$.

Alternatively, EV-like particles can be manufactured from the cellular membrane of cells deprived of cytoplasm and nuclei. These empty nanovesicles, named nanoghosts, were historically produced from $\mathrm{MSCs}^{107}$. They have recently been also produced from other cell types such as macrophages ${ }^{111}$ or monocytes ${ }^{112}$. Oieni et al. ${ }^{113}$ 
evaluated the scalability and robustness of the nanoghost technology. The first step consists in the manufacture of ghost cells, by hypotonic treatment for $5-20$ min followed by an important homogenization step to remove cytosolic content. Then, the membranes are downsized by extrusion or sonication to release the nanoghosts. Coefficients of variance of the main parameters were indicated for over 40 productions: $57 \%$ and $49 \%$ for the lipids and proteins yield respectively, $59 \%$ for the purity and $8 \%$ for the size, which were considered correct if we consider the sources of variability introduced during the process such as the origin the cells or the operators. According to the authors, this robust production platform could be scalable, by using high pressure homogenization systems and microfluidics as well as continuous flow ultracentrifuge for isolation.

Finally, extracellular blebs (EBs) were also described as a promising alternative to EVs. Cellular blebbing has been studied since the 1970's, but it has only been recently proposed as a way to produce EV-like particles by irreversible blebbing ${ }^{114}$. EBs represent an interesting option because they are produced in the presence of a chemical agent such as paraformaldehyde (PFA) or N-Ethylmaleimide (NEM), as quickly as EV-like particles, but without release of intracellular contents. On the other hand, their isolation will require careful removal of these products. In 2018, Ingato et al. ${ }^{108}$ reported a nearly ten-fold increase in protein yield between EB and EV, as well as an enhanced stability.

\section{Comparability between technologies}

After the description of the numerous strategies to address the issue of scaling up EV production, the remaining task is to find a way to compare these technologies. Indeed, the lack of standardization in the processes of isolation and characterization generates a significant variability in the reporting of $\mathrm{EV}$ yield in terms of protein content or particle numbers at different stages of EV isolation. This amounts to poor comparability between technologies as differences in EV yield and purity may highly depend on those aspects. Nonetheless, after a more detailed discussion on EV quantification methods, we will introduce the calculation of a yield factor from only a selected number of publications which quantified EVs in a similar way, and comment on its relevance. We also provide a flowchart of possible production methods in Figure 2.

\subsection{Quantification methods}

Among a variety of techniques that have been developed to detect and quantify EVs ${ }^{115}$, Nanoparticle Tracking Analysis (NTA) and total protein dosage, using colorimetric techniques such as Bradford reagent or bicinchoninic acid (BCA) are the most commonly used to report EV yield. However, these techniques are not specific to EVs. For instance, NTA measures any particle in suspension, including agglomerate of proteins possibly originating from soluble components. Although it is possible to perform labeling with specific fluorescent markers in some set ups of NTA, the lack of report of such data in EV production papers shows this is not a widespread method, contrary to non-specific light scattering of all particles in suspension. Moreover, results obtained from two NTA instruments by the same operator were found different unless settings were optimized ${ }^{116}$, underlying the variability of particle concentration 


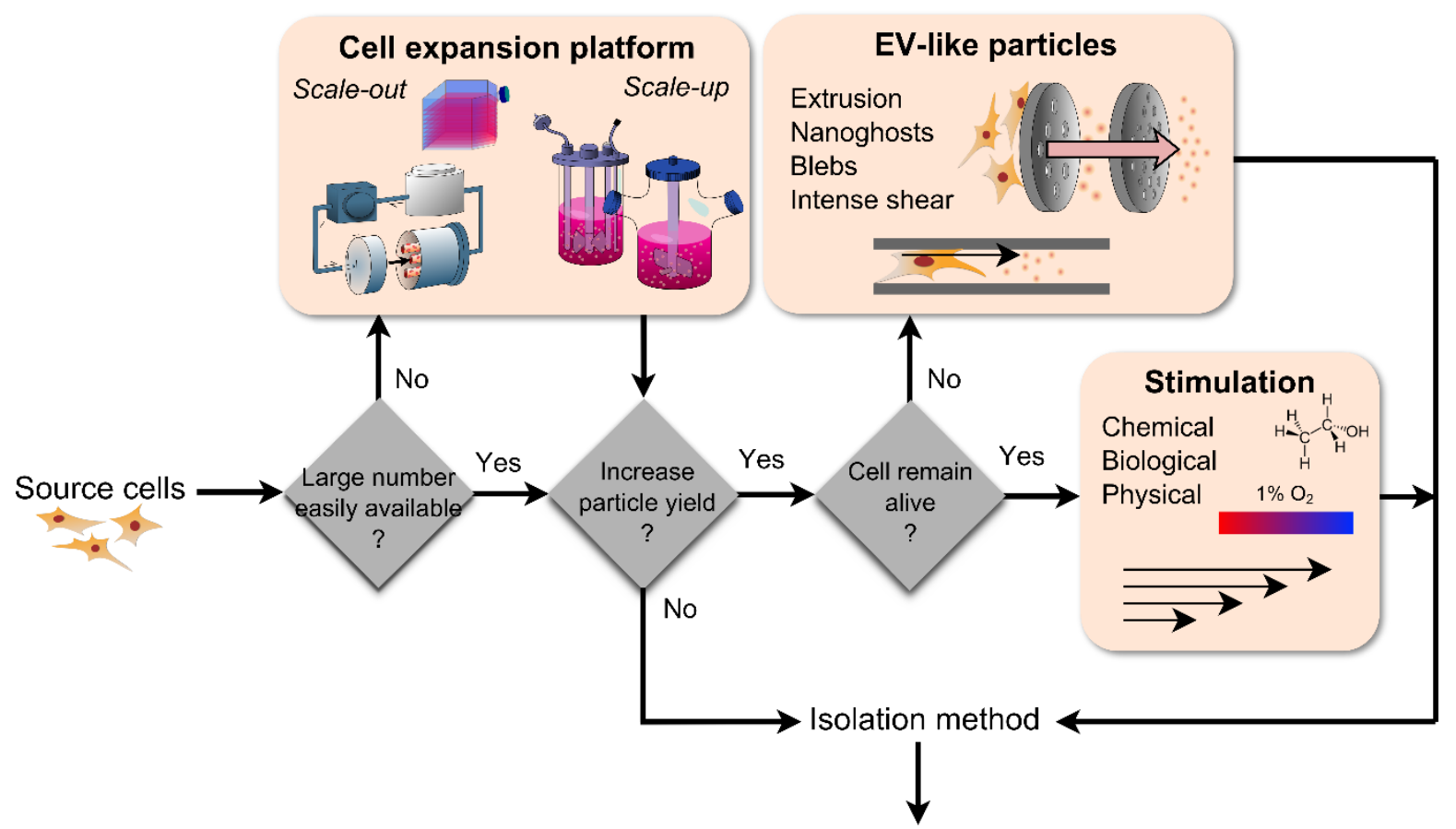

EVs \& EV-like particles

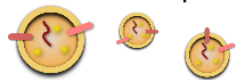

Figure 2 : Flowchart of high-yield EVs and EV-like particles production strategies

measurements between laboratories. Calibration according to commercially available bead standards may improve reproducibility but accurate EV concentration standards would be ideal. By contrast, protein dosage in reference to a calibration curve may be more reproducible from one laboratory to another, but contaminating proteins and interfering agents, such as phenol red or glucose for BCA and detergents for Bradford reagent, may lead to an over-estimation of protein concentration. Absolute values measured for particle or protein concentration thus need to be critically evaluated and compared to control condition. Even then, as these control conditions may have been performed using different media (EV-depleted or serum-free), cell density, etc. such strategy is still limited for inter-studies comparisons.

Another interesting parameter to systematically report is the ratio of particles measured over proteins. However, this parameter is not easily interpreted, as was previously observed. Indeed, considered as a purity parameter for some time for EVs isolated from biological fluids ${ }^{117}$, it is not so relevant as a purity estimator in the case of starvation EVs because the media in itself does not contain many proteins. In this case, increase of particle over protein ratio would rather indicate a loss of protein content from EVs. As this ratio can depend on the production method ${ }^{88}$, it also means that fold change in protein content or in particle concentration compared to control may not be the same, and should probably be both reported separately.

Additionally, quantification of markers enriched in EVs such as CD63, CD9 or CD81 with Western Blot or ELISA tests have been reported. As these techniques are less common, it is difficult to compare between studies, but these results can mitigate and complete a yield obtained in particles or proteins ${ }^{88}$. Similarly, even though many new 
technologies have emerged to quantify EVs, including flow nanocytometry or tunable Resistive Pulse Sensing, reviewed elsewhere ${ }^{118}$, these tools are not yet widely used and hindsight is lacking regarding their reproducibility across laboratories. Moreover, considering affordability, NTA and protein assays might remain the gold standard for quantification of EVs for some time, hence the importance of establishing more standardized procedures with controls and calibration solutions. Combination of different methods to characterize EVs might also continue to be necessary to analyze with better accuracy the identity and properties of EVs.

Taking all this into account, it appears that a yield parameter integrating the many variables at play could be a useful tool to compare large-scale production techniques. The estimation next provided is a tentative approach that may provide valuable insights for comparison.

\subsection{Definition of a yield parameter and application to large-scale approaches}

From a strictly quantitative point of view, EV production is a process which takes as an input a certain amount of cells and yields a number of EVs in a given time, as represented in Figure 3. Thus, one can calculate EV yield as

$$
r=\frac{\text { Total isolated } E V}{\text { Initial cell number } \times \text { Time }}
$$

Here, a particle yield factor has been calculated in amounts of particles per cell per day and a protein yield factor in micrograms of proteins per cell per day.

Depending on the strategy used, cells can be expanded on a culture platform or directly used as raw materials, for instance for extrusion, but in our definition of yield this will only impact the total duration of the process. For example, cell expansion time was calculated for hyperflasks according to seeded cell number (1E8 cells), final cell number measured (700E8 cells) and doubling time (52 h) of CPC.

Table 4 first contains representative yield factors calculated for studies that disclosed sufficient data, with time expressed in days. Importantly, yield factors do not only depend on the production method but is also impacted by the downstream process. This underlines the importance of reporting EV number before isolation in order to better compare different approaches. According to the literature, we can estimate that UC and Density gradient are low yield isolation methods ${ }^{119}$ while SEC is usually reported to have better yield than density gradient while obtaining similar purity ${ }^{120}$ and retains a degree of flexibility with a possible trade-off between higher recovery and more efficient isolation from soluble factors ${ }^{121}$. On the other hand, TFF enrichment process can recover between 7 -fold and 20 -fold more particles than $\mathrm{UC}^{34}$. Considering this, the 3D printed perfusion bioreactor, turbulence in spinner flask as well as most extrusion techniques seem to be promising in terms of quantity of particles obtained at the end of the process, and the 3D printed bioreactor specifically for protein yield Interestingly, Quantum Bioreactor and Fibercell hollow fiber bioreactors, despite being based on the same technology, have very different yields. This is due to the high number of cells seeded in Fibercell systems compared to Quantum bioreactor, which is seeded with only 20 million cells. Moreover, harvests are performed every $48 \mathrm{~h}$ for Quantum bioreactor, which may lead to highest yields. 


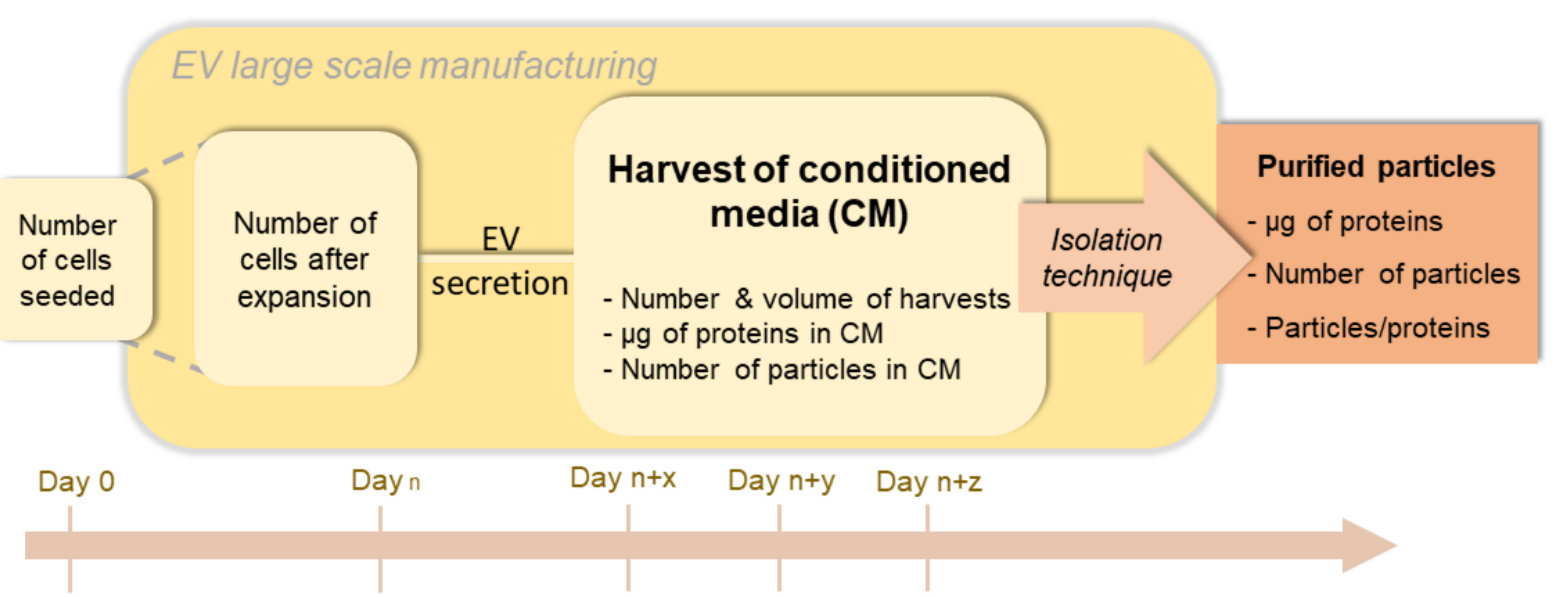

Figure 3 : EV large-scale manufacturing process from a quantitative point of view and suggested information to be reported

Despite the fact that measurements are very difficult to compare from one study to another, because of variations in instruments, settings and operators, as well as different isolation processes, we proposed here the calculation of a factor that would enable us to compare different scale-up strategies solely on particle and protein yield. To implement this tool to future studies, the careful report of parameters listed in Figure 3 would be required. Moreover, as basal protein concentrations in EV-depleted and serum free production media may add a bias in the results, reporting the initial number of particles in the medium at the beginning of EV production would be critical.

However, particle and protein yields are not sufficient to assess the best process for clinical translation. Indeed, adaptation from 2D to 3D culture and physico-chemical stimulations, which impact $E V$ release, also affect $E V$ identity and function probably by activating specific pathways within the mother cells before $E V$ secretion. Besides size, concentration and in a way purity, these changes can only be assessed with additional tools than NTA and protein assays, including flow cytometry, ELISA, omics technologies and potency assays. Further reports of such results would allow metaanalysis of data, giving an insight into the link between production process, EV identity and functionality.

\subsection{Evaluation of functional activity of EVs}

In the end, the foremost concern when evaluating production strategies from a translational point of view is probably EV therapeutic potency. Therefore, Table $\mathbf{5}$ introduces potency assays performed for scale-up approaches, with the aim of providing a more complete description of the prospects of the different methods.

Recognized as biological vectors and actors of paracrine effects, EVs may have several types of bioactivity, mainly their potency as delivery vehicles, their regenerative activity or their immunomodulatory capability. While the internalization of EVs or EVlike particles inside recipient cells is reported at minima in most studies ${ }^{62,79,82,86}$, Jo et al. also demonstrated the transfer of endogenous RNA content from EVs to cells to propose their NVs as EV-mimetic alternatives for drug delivery ${ }^{32,103}$. Another approach is to load EVs with exogenous content in order to study the delivery of this specific cargo, as opposed to the use of naïve EVs. For instance, siRNA have been 
Table 4 : Comparison of yield factors for large-scale production strategies

\begin{tabular}{|c|c|c|c|c|c|c|c|c|c|}
\hline Technology & EV number & $\begin{array}{l}\text { Protein } \\
\text { mass } \\
(\mu \mathrm{g})\end{array}$ & $\begin{array}{l}\text { Cells } \\
\text { seeded }\end{array}$ & Time & $\begin{array}{l}\text { Particle yield } \\
\text { factor } \\
\text { (part/cell/day) }\end{array}$ & $\begin{array}{l}\text { Protein yield } \\
\text { factor }(\mu \mathrm{g} / \text { cell })\end{array}$ & $\begin{array}{l}\text { Isolation } \\
\text { method }\end{array}$ & $\begin{array}{l}\text { Volume } \\
\text { processed }\end{array}$ & Ref \\
\hline $\begin{array}{l}3 \mathrm{D} \\
\text { perfusion } \\
\text { bioreactor }\end{array}$ & 8.7E10 & $1 \mathrm{E3}$ & 1.13E6 & 3 days & 26,000 & $3 \mathrm{E}-4$ & UC & $50 \mathrm{~mL}$ & 88 \\
\hline Extrusion & $\begin{array}{l}2.1 \mathrm{E} 11 \\
3 \mathrm{E} 11\end{array}$ & $\begin{array}{ll}2.1 \mathrm{E} 2 & - \\
3.8 \mathrm{E} 2 & \end{array}$ & $1 \mathrm{E} 7$ & $<1$ day & $21,000-30,000$ & $2-4 E-5$ & Density gradient & $1 \mathrm{~mL}$ & 69,105 \\
\hline $\begin{array}{l}\text { Quantum } \\
\text { bioreactor }\end{array}$ & $\begin{array}{l}9.8 \mathrm{E} 12 \\
1.56 \mathrm{E} 13\end{array}$ & $2 \mathrm{E} 4-3 \mathrm{E} 4$ & $2 \mathrm{E} 7$ & $9+12$ days & $23,000-37,000$ & $5-7 E-5$ & No isolation & $1.5 \mathrm{~L}$ & 29 \\
\hline Hyperflasks & 3E13 & $2.8 \mathrm{E} 5$ & $1 \mathrm{E} 8$ & $20+14$ days & 9,000 & $8 \mathrm{E}-5$ & TFF & $8 \mathrm{~L}$ & 60 \\
\hline Vertical Wheel & $\begin{array}{l}2.8 \mathrm{E} 11 \\
3.1 \mathrm{E} 11 \\
4,1 \mathrm{E} 11\end{array}$ & $\begin{array}{ll}1.4 \mathrm{E} 3 & - \\
1 \mathrm{E} 3 & - \\
1.3 \mathrm{E} 3 & \end{array}$ & $5 \mathrm{E} 6$ & $11-9-12$ days & $4,000-7,000$ & $2 \mathrm{E}-5$ & No isolation & $60 \mathrm{~mL}$ & 28 \\
\hline Fibercell & $1.2 \mathrm{E} 13$ & $8 \mathrm{E} 3$ & $2 \mathrm{E} 8$ & 30 days & 2,000 & $1 \mathrm{E}-5$ & TFF & $0.5-1 \mathrm{~L}$ & 65 \\
\hline $\begin{array}{l}\text { Turbulence } \\
\text { spinner flask }\end{array}$ & $1,4 \mathrm{E} 13$ & $\begin{array}{l}\text { Not } \\
\text { disclosed }\end{array}$ & $3.9 \mathrm{E} 8$ & $<1$ day & 36,000 & Not disclosed & UC & $<1 \mathrm{~L}$ & 92 \\
\hline
\end{tabular}


electroporated into EVs produced from Quantum Bioreactor ${ }^{29}$, or into extrusion NVs ${ }^{105}$, and successful transfer can be easily detected through the silencing of the target gene.

Overall, EV-like particles appear to be a very attractive option for drug delivery applications, such as targeted cancer therapy. In addition to a simpler and higher yield manufacturing process, they seem to deliver cargo as efficiently as 2D EVs, at least in vitro $32,69,105$. In vivo, chemotherapeutics such as doxorubicin ${ }^{69}$, paclitaxel ${ }^{102}$ and STRAIL ${ }^{107}$ as well as siRNA ${ }^{105}$ loaded into NVs, nanoghosts or EBs ${ }^{108}$ were conveyed more selectively to tumor sites than free materials and inhibition of tumor growth and prolonged survival was thus observed in several mice cancer models. Moreover, plasmid DNA loaded in nanoghosts was transferred to recipient cells in vitro and in vivo ${ }^{123}$, evidencing the potential of EV-like particles in gene therapy. On the other hand, despite the common conception that EV-like particles are not as intrinsically bioactive as EVs, Wu et al. also demonstrated that primary hepatocyte derived NVs produced by extrusion possessed intrinsic liver regeneration properties after partial hepatectomy on mice ${ }^{106}$, which only adds further potential to this approach.

Furthermore, 3D culture platforms or chemical and physical stimulation of mother cells have notably been reported to enhance EV potency compared to control 2D EVs in some studies, notably for regeneration of cartilage ${ }^{64}$, kidney ${ }^{122}$, skin ${ }^{88}$ and heart ${ }^{77}$, and for immunostimulation ${ }^{68,81}$. This is why despite the fact that EV production in Fibercell bioreactor or induced by chemical and physical stresses may not yield as many EVs as other strategies, they remain full of potential to obtain specific phenotypes in EVs. In this perspective, Patel et al. combined the two approaches, manufacturing EVs in a scalable platform which have enhanced therapeutic efficacy due to chemical stimulation by ethanol${ }^{88}$. Similarly, our team used stirred tank bioreactors to stimulate cells via shear stress and produce MSC EVs with regenerative properties for fistula therapy ${ }^{91}$, and potential as drug delivery vehicles with enhanced tumor specificity for peritoneal carcinomatosis ${ }^{92}$. Ultimately, the overview of the functional activity of largescale produced EVs confirmed the interest towards these approaches. Among them, EV-like particles strategies and 3D culture potentially combined with priming of mother cells emerge as really promising. Having considered this, we will next present largescale production platforms which are being implemented in current clinical studies.

\section{Production platforms for clinical studies}

As of now, 23 Phase I / II clinical trials are registered on clinicaltrials.gov for testing the treatment of a pathology using human cells derived EVs. The university of Kentucky also has 3 ongoing trials testing plant EVs, and furthermore, there are 9 trials registered with EV-containing products (conditioned media for instance). For most of them, only dozens of patients were treated, with reported doses of EVs in the range of $1 \mathrm{E} 8-1 \mathrm{E} 10$ EVs per injection per patient, which requires medium-scale manufacturing and no specific scale-up strategy was used. However, while this may be feasible for up to about a hundred participants, depending on the dose of EVs, for later stages of trials, large-scale manufacturing processes need to be developed. Ongoing clinical trials for EV-based treatments with more than 90 patients or clear scale-up strategies are indicated in Table 6, EV number being reported without disclosure of measurement method. 
Table 5: Functional activity of EVs or EV-like particles produced by large-scale approaches. Blue: Delivery potency; Pink: regenerative properties; Orange: immunomodulatory effect.

\begin{tabular}{|c|c|c|c|c|c|}
\hline Approach & $\begin{array}{l}\text { Naïve or engineered } \\
\text { EVs }\end{array}$ & Potency in vitro & Potency in vivo & $\begin{array}{l}\text { Comparison } \\
\text { 2D EVs }\end{array}$ & Ref \\
\hline \multicolumn{6}{|c|}{ Cell culture platforms } \\
\hline \multirow[t]{3}{*}{ Hollow fiber } & $\begin{array}{l}\text { hetIL15 on HEK293-EV } \\
\text { surface }\end{array}$ & Uptake and Natural killer cell activation & $\begin{array}{l}\text { Uptake in tumors in mice with breast } \\
\text { cancer }\end{array}$ & - & 62 \\
\hline & Naïve UC-MSC EVs & $\begin{array}{l}\text { Stimulation of chondrocyte proliferation, } \\
\text { migration, matrix synthesis }\end{array}$ & $\begin{array}{l}\text { Regenerative effect in a cartilage defect } \\
\text { model in rabbit }\end{array}$ & Enhanced & 64 \\
\hline & Naïve UC-MSC EVs & $\begin{array}{l}\text { Uptake and increase of viability in tubular } \\
\text { epithelial cells treated with cisplatin }\end{array}$ & $\begin{array}{l}\text { Renoprotective and anti-inflammatory } \\
\text { effect in a cisplatin induced model of acute } \\
\text { kidney injury in mice }\end{array}$ & Enhanced & 122 \\
\hline \multirow[t]{2}{*}{ Hyperflasks } & Naïve BM-MSC & $\begin{array}{l}\text { Decrease in } \mathrm{T} \text { lymphocyte activation } \\
\text { (dependent of donor) }\end{array}$ & $\begin{array}{l}\text { Improvement of graft-versus-host disease } \\
\text { symptoms in mice (dependent on donor) }\end{array}$ & - & 59 \\
\hline & Naïve CPC EVs & $\begin{array}{l}\text { Anti-apoptotic effect on staurosporine } \\
\text { treated CPC and pro-angiogenic activity }\end{array}$ & $\begin{array}{l}\text { Regenerative efficacy in rat model of } \\
\text { permanent coronary artery occlusion }\end{array}$ & - & 60 \\
\hline Spinner flasks & $\begin{array}{l}\text { UC-MSC EVs loaded with } \\
\text { siRNA targeting Huntingtin } \\
\text { gene }\end{array}$ & $\begin{array}{l}\text { Efficient Huntingtin silencing by siRNA } \\
\text { transfer in neurons }\end{array}$ & - & Enhanced & 34 \\
\hline Quantum bioreactor & $\begin{array}{l}\text { MSC EV electroporated } \\
\text { with siRNA targeting } \\
\text { oncogenic Kras gene }\end{array}$ & $\begin{array}{l}\text { Induction of apoptosis in pancreatic } \\
\text { cancer cells with Kras mutation and } \\
\text { downregulation of Kras expression }\end{array}$ & $\begin{array}{l}\text { Improve survival and decrease metastatic } \\
\text { burden in pancreatic ductal } \\
\text { adenocarcinoma model on mice }\end{array}$ & Similar & 29 \\
\hline CELLine & $\begin{array}{l}\text { Naïve mesothelial cell } \\
\text { derived EVs }\end{array}$ & Anti-proliferative effect on lymphocytes & - & Similar & 57 \\
\hline \multicolumn{6}{|c|}{ Chemical \& Physical stimulation of cells } \\
\hline $\begin{array}{l}\text { Shear stress in } \\
\text { perfusion bioreactor }\end{array}$ & $\begin{array}{l}\text { Naïve and ethanol treated } \\
\text { HDMEC EVs }\end{array}$ & $\begin{array}{l}\text { Increased gap closure for dermal } \\
\text { microvascular endothelial cells }\end{array}$ & - & Enhanced & 88 \\
\hline \multirow[t]{2}{*}{$\begin{array}{l}\text { Shear stress in } \\
\text { spinner flasks }\end{array}$} & $\begin{array}{lr}\text { Naïve murine MSC } & \text { EVs } \\
\text { administered } & \text { in } \\
\text { thermoresponsive gel } & \end{array}$ & - & $\begin{array}{l}\text { Decreased fistula output and orifice } \\
\text { diameter in rat model of colo-cutaneous } \\
\text { post-surgical fistula }\end{array}$ & - & 91 \\
\hline & $\begin{array}{l}\text { mTHPC loaded murine } \\
\text { MSC EVs }\end{array}$ & - & $\begin{array}{l}\text { Increased tumoral selectivity and } \\
\text { prolonged survival in mice colorectal } \\
\text { carcinomatosis model }\end{array}$ & - & 92 \\
\hline Hypoxia & Naïve murine MSC EVs & $\begin{array}{l}\text { Uptake and decreased apoptosis in } \\
\text { cardiomyoblasts, pro-angiogenic activity }\end{array}$ & $\begin{array}{l}\text { Cardiac protective activity and prolonged } \\
\text { survival in a mice infarct model }\end{array}$ & Enhanced & 77 \\
\hline Low $\mathrm{pH}$ & Naïve melanoma cells EVs & Uptake by tumor cells & - & Enhanced & 79 \\
\hline Glucose deprivation & Naïve H9C2 EVs & Pro-angiogenic activity & - & Enhanced & 87 \\
\hline Heat shock & Naïve 3LL EVs & $\begin{array}{l}\text { Chemoattraction and activation of } \\
\text { dendritic cells and T cells }\end{array}$ & $\begin{array}{l}\text { Increased infiltration of } \mathrm{T} \text { cells and } \\
\text { dendritic cells into tumor, inhibition of } \\
\text { tumor growth an prolonged survival in } \\
\text { mice lung cancer model }\end{array}$ & Enhanced & 81 \\
\hline
\end{tabular}




\begin{tabular}{|c|c|c|c|c|c|}
\hline \multirow[t]{2}{*}{ Ethanol } & Naïve hepatocyte EVs & $\begin{array}{l}\text { Uptake in monocytes and transfer of } \\
\text { miRNA-122, increasing pro-inflammatory } \\
\text { effect in the presence of LPS }\end{array}$ & - & Enhanced & 41 \\
\hline & Naïve monocyte EVs & $\begin{array}{l}\text { Stimulation of naïve monocytes towards } \\
\text { M2 polarization }\end{array}$ & - & Enhanced & 68 \\
\hline $\begin{array}{l}\text { Low intensity } \\
\text { ultrasound }\end{array}$ & $\begin{array}{l}\text { Naïve ovarian cancer cell } \\
\text { EVs }\end{array}$ & - & $\begin{array}{l}\text { Biodistribution of labeled EVs in mice, no } \\
\text { immunogenicity }\end{array}$ & Similar & 82 \\
\hline $\begin{array}{l}\text { Incubation with } \\
\text { liposomes }\end{array}$ & $\begin{array}{l}\text { Naïve EVs secreted in the } \\
\text { presence of cationic bare } \\
\text { liposomes }\end{array}$ & Uptake in cancer cells & - & $\begin{array}{l}\text { Enhanced or } \\
\text { reduced } \\
\text { (dependent on } \\
\text { liposome) }\end{array}$ & 86 \\
\hline \multicolumn{6}{|c|}{ EV-like particles } \\
\hline \multirow[t]{5}{*}{ Extrusion } & Naïve mES EVs & $\begin{array}{l}\text { Uptake in epithelial cells and transfer of } \\
\text { endogenous RNA }\end{array}$ & - & Similar & 32 \\
\hline & $\begin{array}{lr}\text { MCF-10A } & E V s \\
\text { electroporated with } & \text { CDK4 } \\
\text { targeting siRNA }\end{array}$ & $\begin{array}{l}\text { Uptake, downregulation of CDK4 and } \\
\text { arrest of cell cycle in MCF-7 cells }\end{array}$ & $\begin{array}{l}\text { Increased tumoral selectivity an tumor } \\
\text { growth inhibition in subcutaneous MCF-7 } \\
\text { tumor xenograft mice }\end{array}$ & $\begin{array}{l}\text { Similar } \\
\text { vitro) }\end{array}$ & 105 \\
\hline & $\begin{array}{l}\text { U937 and Raw264.7 NVs } \\
\text { loaded with doxorubicin }\end{array}$ & $\begin{array}{l}\text { Delivery of doxorubicin to TNF- } \alpha \\
\text { endothelial cells inducing cytotoxicity }\end{array}$ & $\begin{array}{l}\text { Increased tumoral selectivity and anti- } \\
\text { tumoral effect on mice colorectal cancer } \\
\text { model }\end{array}$ & $\begin{array}{l}\text { Similar } \\
\text { vitro) }\end{array}$ & 69 \\
\hline & $\begin{array}{l}\text { BM-MSC NVs loaded with } \\
\text { paclitaxel }\end{array}$ & $\begin{array}{l}\text { Delivery of paclitaxel to breast cancer and } \\
\text { normal breast cells inducing cytotoxicity }\end{array}$ & $\begin{array}{l}\text { Reduced tumor growth mice breast } \\
\text { cancer model }\end{array}$ & - & 102 \\
\hline & $\begin{array}{l}\text { Naïve murine } \\
\text { hepatocytes NVs }\end{array}$ & $\begin{array}{l}\text { Increase proliferation of primary } \\
\text { hepatocytes }\end{array}$ & $\begin{array}{l}\text { Liver regenerative effect after partial } \\
\text { hepatectomy in mice }\end{array}$ & - & 106 \\
\hline $\begin{array}{l}\text { Microfluidic } \\
\text { channels }\end{array}$ & mESC NVs & $\begin{array}{l}\text { Uptake in fibroblast and transfer of } \\
\text { endogenous RNA }\end{array}$ & - & Similar & 103 \\
\hline Slicing blades & $\begin{array}{l}\text { mESCs NVs loaded with } \\
\text { polystyrene fluorescent } \\
\text { beads }\end{array}$ & $\begin{array}{l}\text { Delivery of encapsulated beads to } \\
\text { fibroblasts }\end{array}$ & - & - & 33 \\
\hline \multirow[t]{2}{*}{ Nanoghosts } & sTRAIL loaded MSC-NGs & $\begin{array}{l}\text { Uptake and cytotoxicity in prostate cancer } \\
\text { cells }\end{array}$ & $\begin{array}{l}\text { Accumulation of NGs in tumor and in liver, } \\
\text { inhibition of tumor growth in mice prostate } \\
\text { cancer model }\end{array}$ & - & 107 \\
\hline & $\begin{array}{l}\text { cancer-toxic gene encoding } \\
\text { pDNA loaded MSC-NGs }\end{array}$ & $\begin{array}{l}\text { Gene delivery of pDNA inducing } \\
\text { cytotoxicity in prostate cancer cells }\end{array}$ & $\begin{array}{l}\text { Inhibition of tumor growth and metastasis, } \\
\text { prolonged survival in mice prostate and } \\
\text { lung cancer }\end{array}$ & & 123 \\
\hline $\begin{array}{lll}\text { PFA } & + & \text { DTT } \\
\text { (extracellular blebs) }\end{array}$ & $\begin{array}{l}\text { Doxorubicin loaded } \text { EL4 } \\
\text { EBs }\end{array}$ & $\begin{array}{l}\text { Release of doxorubicin from EBs inducing } \\
\text { cytotoxicity on EL-4 cells }\end{array}$ & $\begin{array}{l}\text { Reduced tumor growth and prolonged } \\
\text { survival in mice lymphoma cancer model }\end{array}$ & - & 108 \\
\hline
\end{tabular}


Table 6: Scale-up strategies adopted in clinics

\begin{tabular}{|c|c|c|c|c|c|c|}
\hline $\begin{array}{l}\text { Company / } \\
\text { Institute }\end{array}$ & Phase I/II clinical study & $\begin{array}{l}\mathrm{Nb} \text { of } \\
\text { pat- } \\
\text { ients }\end{array}$ & $\begin{array}{l}\text { Number of EVs } \\
\text { (total) }\end{array}$ & $\begin{array}{l}\text { Treatment per } \\
\text { patient }\end{array}$ & $\begin{array}{l}\text { Source of } \\
\text { EVs }\end{array}$ & $\begin{array}{l}\text { Scale-up strategies reported in patent } \\
\text { or publication by main investigator }\end{array}$ \\
\hline $\begin{array}{l}\text { Codiak } \\
\text { Biosciences }\end{array}$ & $\begin{array}{l}\text { A First-in-Human Study of } \text { CDK-002 } \\
\text { (exoSTING) in Subjects With } \\
\text { Advanced/Metastatic, } \\
\text { Injectable Solid Tumors } \\
\text { (NCT04592484) }\end{array}$ & 180 & Not disclosed & Not disclosed & hMSC & $\begin{array}{l}\text { Quantum bioreactor, Terumo } \\
\text { WAVE bioreactor } \\
50 \mathrm{~L} \text { fed batch bioreactor }\end{array}$ \\
\hline $\begin{array}{l}\text { Ruijin } \\
\text { Hospital }\end{array}$ & $\begin{array}{l}\text { A Clinical Study of Mesenchymal Stem } \\
\text { Cell Exosomes Nebulizer for the } \\
\text { Treatment of ARDS } \\
\text { (NCT04602104) }\end{array}$ & 169 & $2 \mathrm{E} 12$ & $\begin{array}{l}\text { 2E8 / 8E8 / 16E8 } \\
\text { EVs inhaled every } \\
\text { day for } 7 \text { days }\end{array}$ & hMSC & Not disclosed \\
\hline $\begin{array}{l}\text { Samara } \\
\text { Regional } \\
\text { Medical } \\
\text { Center } \\
\text { Dinasty }\end{array}$ & 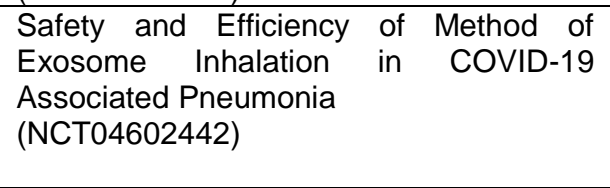 & 90 & $2.5 \mathrm{E} 13$ & $\begin{array}{l}0.5-2 E 10 \text { EVs } \\
\text { inhaled twice a day } \\
\text { for } 10 \text { days }\end{array}$ & hMSC & $\begin{array}{l}\text { Hollow fiber or microcarrier based } \\
\text { approach }\end{array}$ \\
\hline Exopharm & $\begin{array}{l}\text { PLEXOVAL II : safety and benefits in } \\
\text { wound healing of platelet derived EVs }\end{array}$ & 15 & Not disclosed & Not disclosed & Platelets & $\begin{array}{l}\text { EVs isolated directly from donors platelets } \\
\text { with patented isolation technology LEAP }\end{array}$ \\
\hline $\begin{array}{l}\text { James } \\
\text { Graham } \\
\text { Brown } \\
\text { Cancer } \\
\text { Center }\end{array}$ & $\begin{array}{l}\text { Plant Exosomes and Patients Diagnosed } \\
\text { With Polycystic Ovary Syndrome (PCOS) } \\
17 \text { (NCT03493984) }\end{array}$ & 176 & Not disclosed & Not disclosed & $\begin{array}{l}\text { Ginger EV- } \\
\text { like particles, } \\
\text { Aloe vera } \\
\text { EV-like } \\
\text { particles }\end{array}$ & Raw materials available in large quantities \\
\hline Aposcience & $\begin{array}{l}\text { A Study to Evaluate Safety and Efficacy of } \\
\text { APO-2 at Three Different Doses in } \\
\text { Patients With Diabetic Foot Ulcer } \\
\text { (NCT04277598) }\end{array}$ & 132 & $\begin{array}{l}\text { EV-like particles } \\
\text { produced by } \\
50 \mathrm{E} 10 \mathrm{PBMC}\end{array}$ & $\begin{array}{l}0.5 \mathrm{~mL} \text { per } \mathrm{cm}^{2} \text { of } \\
\text { wound of secretome } \\
\text { from } 12.5 / 25 / 50 \\
\text { million PBMC } 3 \\
\text { times a week for } 4 \\
\text { weeks }\end{array}$ & PBMC & Raw materials available in large quantities \\
\hline
\end{tabular}


The production platforms which have been identified are reviewed in the following, acknowledging however that many companies prefer not to disclose details about their production methods and their yield. Moreover, advancement of different cell expansion platforms towards clinical application is represented in Figure 4.

After a successful evaluation of safety in 25 healthy volunteers of exolL12 (EVs exposing an active form of IL12 on the membrane) ${ }^{124}$, Codiak BioSciences has started to recruit 180 participants to test their second engineered EV product for the treatment of solid metastatic tumors (NCT 04592484). Codiak Biosciences is one of the major pharmaceutical companies leading research on EVs and has a large portfolio of patents on EV technology. They have identified two EV-associated membrane proteins, PTGFRN (facing the exterior of the membrane) and BASP-1 (facing the lumen), which they use as scaffolds to link molecules of interest and engineer EVs to promote a specific therapeutic application. It is from this engineering platform, termed engEx ${ }^{\mathrm{TM}}$, that they created two of their more advanced products, exoSTING (EVs enriched in stimulator of interferon genes in the lumen), and exolL12. Recently, the use of a Quantum bioreactor was reported to produce 1E13 particles in Pr. Kalluri's team ${ }^{29}$, who is a scientific advisor of Codiak Biosciences, suggesting the use of perfusion bioreactor from the company to scale up MSC-EV production. Moreover, Codiak patented the production of EVs in single-cell suspension within chemically defined culture media (US20190085284A1) in which they showed that they obtained 3E15 particles from a 2.4 L perfusion bioreactor containing 40E6 HEK cells $/ \mathrm{mL}$ in 12 days, preferentially than from $50 \mathrm{~L}$ fed batch culture. On the other hand, the company also reported the use of Wave bioreactor for the large-scale culture of HEK293 and production of $E V s$, with 10 or $25 \mathrm{~L}$ working volumes ${ }^{125}$.

In the wake of the COVID19 sanitary crisis, the Ruijin Hospital, attached to the University of Medicine of Shangai, has initiated several trials to study the safety, tolerability and efficacy of aerosol inhalation of allogenic MSC EVs for the treatment of pulmonary infection and Acute Respiratory Distress Syndrome in collaboration with Cellular Biomedicine Group (NCT04544215, NCT04276987, NCT04313647). Their largest trial so far (NCT04602104) will involve 169 participants divided in 6 groups. The manufacturing conditions of EVs are not detailed, however, as the inhalation dose proposed does not exceed 1.6E9 EVs, even with 7 inhalations planned per patient, this would at most require $2 \mathrm{E} 12 \mathrm{EVs}$ which is still manageable to produce with $2 \mathrm{D}$ flask culture. The Health Facility "Samara Regional Medical Center Dinasty" in Russia also completed a first trial evaluating safety and efficacy of inhaled MSC-EVs in Sars-CoV2 associated pneumonia. Their next trial, enrolling participants by invitation, may require up to $2.5 \mathrm{E} 13 \mathrm{EVs}$ which is more challenging to produce by conventional methods. Although no manufacturing method is described either, according to the patent filed by O. Tyumina concerning the process of obtaining and concentrating MSC-EVs, they could consider hollow fiber bioreactor or microcarriers approaches to scale up their culture $^{126}$ (RU2710368C2).

EV-like particles are also investigated in clinical trials, proposing an alternative to scale up with the use of more available sources of cells. For instance, three clinical studies from the James Graham Brown Cancer Center in Louisville, USA, are testing the efficacy of plant EV-like particles for the treatment of pathologies associated with 
Strategies

SCALE-OUT

2D flasks

Hyperflasks

Hollow fiber

bioreactor

Integra CELLine

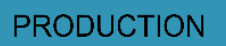

FEASIBILITY

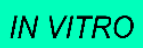

TESTS
IN VIVO

TESTS

\section{SCALE-UP}
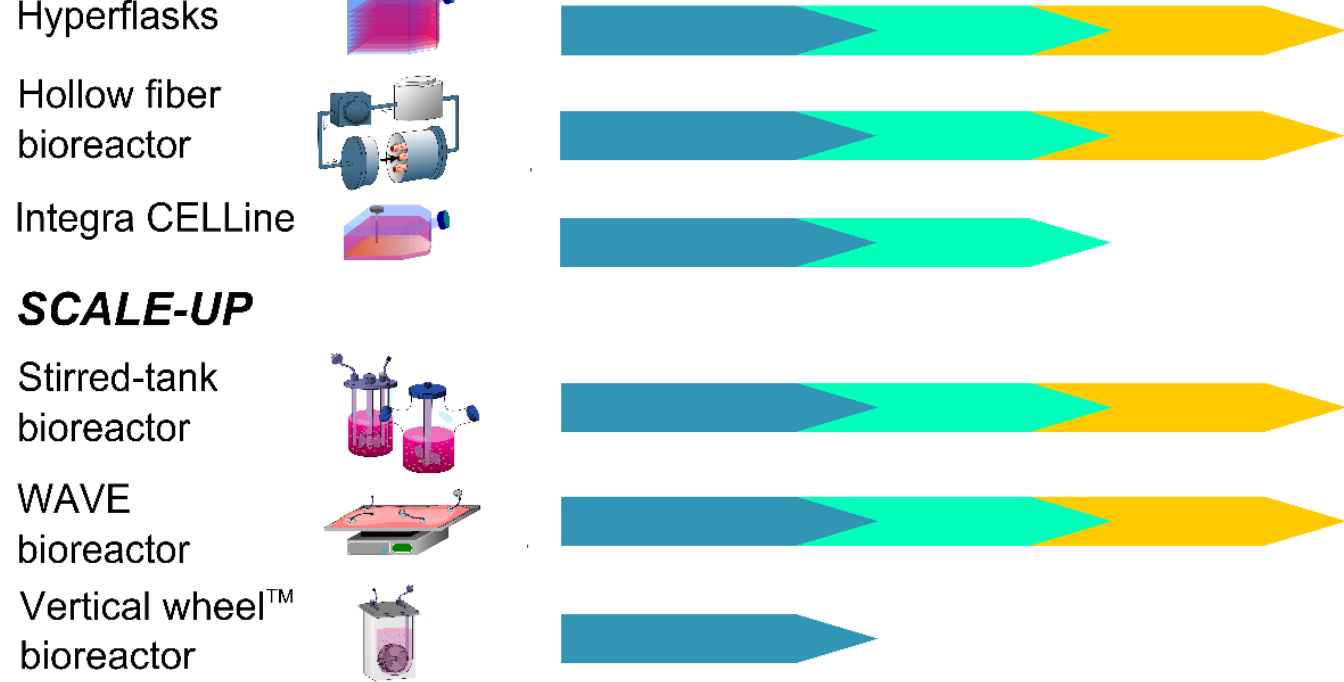

\section{Figure 4: Pipelines of cell expansion platforms}

cancer (NCT01294072, NCT03493984, NCT01668849), more specifically particles isolated from aloe vera, ginger or grape. While plant EVs may not have similar bioactivity than human cell derived EVs, they still can be used as drug delivery vehicles ${ }^{127}$. On the other hand, the company Exopharm has initiated its second clinical trial, PLEXOVAL II, a Phase I study evaluating safety of platelet derived EVs for wound healing treatment with 20 participants ${ }^{128}$. The company has patented their Ligandbased Exosomes Affinity Purification (LEAP) technology, which allows them to isolate EVs directly from large volumes of pooled platelet packs at a low cost and in less than one day. They manufactured 40 doses of EVs from $2 \mathrm{~L}$ of platelets in $8 \mathrm{~h}$ from purification to final product, and propose a scale-up strategy from 40 to 4,000 doses by upscaling the amount of raw materials, the equipment size and automated vial filling. The company also plans to develop their MSC EV product, isolated from stromal cell conditioned media by LEAP, and initiate Phase I clinical study. In a similar approach, Aposciences is developing a secretome product obtained from the irradiation of peripheral blood mononuclear cells, which has been shown to promote wound healing ${ }^{129}$. The results of a Phase I study, MARYSAS I, showed the safety of administrating the secretome produced by 25E6 PBMC. MARYSAS II, now recruiting 132 participants with diabetic foot ulcer, will evaluate the safety and efficacy of APOSEC. The treatment will consist in topical administration of APOSEC at different dosages three times per week for 4 weeks. Because the raw material can be easily procured, the scalability of this approach is promising.

Finally, on can note that, except for Codiak BioSciences, the most advanced scale-up strategies which have been disclosed preferentially use large quantities of available raw materials and produce EV-like particles or secretome based products. This could be explained, as was pointed out in Beer et al. ${ }^{75}$, by the fact that access to blood products entails a collaboration with blood banks, which already possess expertise in 
GMP processes and certifications, facilitating and accelerating the clinical translation of EV-based products. Overcoming challenges of EV production and increasing robustness of characterization methods will hopefully pave the way towards a multiplication of large-scale EV clinical trials.

\section{Conclusion}

Several strategies have been tested to develop the large-scale manufacturing of EVs these last few years. Depending on the availability of cell source, expansion may be required on cellular platforms such as hollow fiber or stirred tank bioreactors. Chemical or physical stimulation can also be considered, as a way to increase EV yield. To drastically increase particle yield, another approach is to disrupt cell membrane and create auto-assembled EV-mimetic particles which retain EV drug delivery potency. Due to the lack of characterization standards, comparison between studies is complex and better comparison tools must be developed, which is why we proposed here a tentative approach to estimate yield factors that could be used to evaluate production methods. To this day, most large-scale clinical studies employ plant vesicles or EVbased products obtained from blood-derived cells, as they are more easily available source of vesicles. Most recent technological advances in production methods which report similar or enhanced EV therapeutic potency compared to EVs produced in flasks should facilitate the implementation of phase III clinical studies and ultimately the transition from cells to EV therapy. 


\section{Abbreviations}

EV: extracellular vesicles

NV: nanovesicles

EB: extracellular blebs

MSC: mesenchymal stromal cells

MSC EV: mesenchymal stromal cell derived extracellular vesicles

UC MSC: umbilical cord derived mesenchymal stromal cells

BM MSC: bone marrow derived mesenchymal stromal cells

ASC: adipose tissue derived mesenchymal stromal cells

HDMEC: human dermal microvascular endothelial cells

HUVEC: human umbilical vein endothelial cells

CPC: cardiac progenitor cells

HEK293: human embryonic kidney 293 cells

PBMC: peripheral blood mononuclear cells

RBC: red blood cells

MWCO: molecular weight cut off

NTA: Nanoparticle Tracking Analysis

BCA: bicinchoninic acid

ELISA: enzyme-linked immunosorbent assay

TEM: transmission electron microscopy

UC : ultracentrifugation

TFF: tangential flow filtration

SEC: Size exclusion chromatography

GMP: Good Manufacturign Practices

hetIL-15: interleukin 15 in heterodimeric form

TNF- $\alpha$ : tumor necrosis factor alpha

IL8: interleukin 8

LTB4: leukotriene B4

PEG: polyethylene glycol

PLGA-PEI: poly(lactic-co-glycolic acid) - polyethylenimine

PFA: paraformaldehyde

DTT: dithiothreitol

mTHPC: meta(tetrahydroxyphenyl)chlorin

STRAIL: soluble form of tumor necrosis factor-related apoptosis-inducing ligand

PTGFRN : Prostaglandin F2 receptor negative regulator

BASP-1 : Brain acid soluble protein 1

\section{Acknowledgements}

This study was supported by the IdEx Universite de Paris, ANR-18-IDEX-0001 and by the Region lle de France under the convention SESAME 2019 - IVETh ( $n^{\circ}$ EX047011). "This project has received funding from the European Research Council (ERC) under the European Union's Horizon 2020 research and innovation programme (grant agreement No. 852791 and 648779). 


\section{References}

1. Rani, S., Ryan, A. E., Griffin, M. D. \& Ritter, T. Mesenchymal Stem Cell-derived Extracellular Vesicles: Toward Cell-free Therapeutic Applications. Mol. Ther. 23, 812-823 (2015).

2. De Jong, O. G., Van Balkom, B. W. M., Schiffelers, R. M., Bouten, C. V. C. \& Verhaar, M. C. Extracellular Vesicles: Potential Roles in Regenerative Medicine. Front. Immunol. 5, (2014).

3. Andaloussi, S. E., Mäger, I., Breakefield, X. O. \& Wood, M. J. A. Extracellular vesicles: biology and emerging therapeutic opportunities. Nat. Rev. Drug Discov. 12, 347-357 (2013).

4. Cabral, J., Ryan, A. E., Griffin, M. D. \& Ritter, T. Extracellular vesicles as modulators of wound healing. Adv. Drug Deliv. Rev. 129, 394-406 (2018).

5. Qin, Y., Wang, L., Gao, Z., Chen, G. \& Zhang, C. Bone marrow stromal/stem cell-derived extracellular vesicles regulate osteoblast activity and differentiation in vitro and promote bone regeneration in vivo. Sci. Rep. 6, 21961 (2016).

6. Alcaraz, M. J., Compañ, A. \& Guillén, M. I. Extracellular Vesicles from Mesenchymal Stem Cells as Novel Treatments for Musculoskeletal Diseases. Cells 9, 98 (2020).

7. de Abreu, R. C. et al. Native and bioengineered extracellular vesicles for cardiovascular therapeutics. Nat. Rev. Cardiol. 17, 685-697 (2020).

8. Szabo, G. \& Momen-Heravi, F. Extracellular vesicles in liver disease and potential as biomarkers and therapeutic targets. Nat. Rev. Gastroenterol. Hepatol. 14, 455-466 (2017).

9. Grange, C., lampietro, C. \& Bussolati, B. Stem cell extracellular vesicles and kidney injury. Stem Cell Investig. 4, (2017).

10. Fujita, Y., Kadota, T., Araya, J., Ochiya, T. \& Kuwano, K. Clinical Application of Mesenchymal Stem Cell-Derived Extracellular Vesicle-Based Therapeutics for Inflammatory Lung Diseases. J. Clin. Med. 7, 355 (2018).

11. Doeppner, T. R., Bähr, M., Giebel, B. \& Hermann, D. M. Immunological and nonimmunological effects of stem cell-derived extracellular vesicles on the ischaemic brain. Ther. Adv. Neurol. Disord. 11, 1756286418789326 (2018).

12. Andjus, P. et al. Extracellular Vesicles as Innovative Tool for Diagnosis, Regeneration and Protection against Neurological Damage. Int. J. Mol. Sci. 21, 6859 (2020).

13. Robbins, P. D. \& Morelli, A. E. Regulation of immune responses by extracellular vesicles. Nat. Rev. Immunol. 14, 195-208 (2014).

14. Vader, P., Mol, E. A., Pasterkamp, G. \& Schiffelers, R. M. Extracellular vesicles for drug delivery. Adv. Drug Deliv. Rev. 106, 148-156 (2016).

15. Mizrak, A. et al. Genetically Engineered Microvesicles Carrying Suicide mRNA/Protein Inhibit Schwannoma Tumor Growth. Mol. Ther. 21, 101-108 (2013).

16. Zhang, Y. et al. Microvesicle-mediated delivery of transforming growth factor $\beta 1$ siRNA for the suppression of tumor growth in mice. Biomaterials 35, 4390-4400 (2014).

17. Tang, K. et al. Delivery of chemotherapeutic drugs in tumour cell-derived microparticles. Nat. Commun. 3, 1282 (2012).

18. Besse, B. et al. Dendritic cell-derived exosomes as maintenance immunotherapy after first line chemotherapy in NSCLC. Oncoimmunology 5, e1071008 (2016).

19. Web of Science. https://apps.webofknowledge.com. Last access $\mathbf{3 0}$ March 2021.

20. Google Patents. https://patents.google.com/. Last access 30 March 2021.

21. Clinical trials gov. https://clinicaltrials.gov. Last access $\mathbf{3 0}$ March 2021. 
22. Worthington, E. N. \& Hagood, J. S. Therapeutic Use of Extracellular Vesicles for Acute and Chronic Lung Disease. Int. J. Mol. Sci. 21, 2318 (2020).

23. Mahida, R. Y., Matsumoto, S. \& Matthay, M. A. Extracellular Vesicles: A New Frontier for Research in Acute Respiratory Distress Syndrome. Am. J. Respir. Cell Mol. Biol. 63, 15-24 (2020).

24. Théry, C. et al. Minimal information for studies of extracellular vesicles 2018 (MISEV2018): a position statement of the International Society for Extracellular Vesicles and update of the MISEV2014 guidelines. J. Extracell. Vesicles 7, 1535750 (2018).

25. Börger, V. et al. International Society for Extracellular Vesicles and International Society for Cell and Gene Therapy statement on extracellular vesicles from mesenchymal stromal cells and other cells: considerations for potential therapeutic agents to suppress coronavirus disease- 19 . Cytotherapy 22, 482-485 (2020).

26. Moleirinho, M. G., Silva, R. J. S., Alves, P. M., Carrondo, M. J. T. \& Peixoto, C. Current challenges in biotherapeutic particles manufacturing. Expert Opin. Biol. Ther. 20, 451-465 (2020).

27. Adlerz, K., Patel, D., Rowley, J., Ng, K. \& Ahsan, T. Strategies for scalable manufacturing and translation of MSC-derived extracellular vesicles. Stem Cell Res. 48, 101978 (2020).

28. de Almeida Fuzeta, M. et al. Scalable Production of Human Mesenchymal Stromal CellDerived Extracellular Vesicles Under Serum-/Xeno-Free Conditions in a Microcarrier-Based Bioreactor Culture System. Front. Cell Dev. Biol. 8, 553444 (2020).

29. Mendt, M. et al. Generation and testing of clinical-grade exosomes for pancreatic cancer. JCI Insight 3,.

30. Headland, S. E., Jones, H. R., D'Sa, A. S. V., Perretti, M. \& Norling, L. V. Cutting-Edge Analysis of Extracellular Microparticles using ImageStream X Imaging Flow Cytometry. Sci. Rep. 4, 5237 (2014).

31. Piffoux, M. et al. Extracellular Vesicle Production Loaded with Nanoparticles and Drugs in a Trade-off between Loading, Yield and Purity: Towards a Personalized Drug Delivery System. Adv. Biosyst. 1, 1700044 (2017).

32. Jo, W. et al. Large-scale generation of cell-derived nanovesicles. Nanoscale 6, 12056-12064 (2014).

33. Yoon, J. et al. Generation of nanovesicles with sliced cellular membrane fragments for exogenous material delivery. Biomaterials 59, 12-20 (2015).

34. Haraszti, R. A. et al. Exosomes Produced from 3D Cultures of MSCs by Tangential Flow Filtration Show Higher Yield and Improved Activity. Mol. Ther. 26, 2838-2847 (2018).

35. Watson, D. C. et al. Scalable, cGMP-compatible purification of extracellular vesicles carrying bioactive human heterodimeric IL-15/lactadherin complexes. J. Extracell. Vesicles 7, 1442088 (2018).

36. Golpanian, S. et al. Concise Review: Review and Perspective of Cell Dosage and Routes of Administration From Preclinical and Clinical Studies of Stem Cell Therapy for Heart Disease. STEM CELLS Transl. Med. 5, 186-191 (2016).

37. Gronemeyer, P., Ditz, R. \& Strube, J. Trends in Upstream and Downstream Process Development for Antibody Manufacturing. Bioengineering 1, 188-212 (2014).

38. Sun, L. et al. Serum deprivation elevates the levels of microvesicles with different size distributions and selectively enriched proteins in human myeloma cells in vitro. Acta Pharmacol. Sin. 35, 381-393 (2014).

39. King, H. W., Michael, M. Z. \& Gleadle, J. M. Hypoxic enhancement of exosome release by breast cancer cells. BMC Cancer 12, 421 (2012). 
40. Piffoux, M. et al. Extracellular vesicles for personalized medicine: The input of physically triggered production, loading and theranostic properties. Adv. Drug Deliv. Rev. 138, 247-258 (2019).

41. Momen-Heravi, F., Bala, S., Kodys, K. \& Szabo, G. Exosomes derived from alcohol-treated hepatocytes horizontally transfer liver specific miRNA-122 and sensitize monocytes to LPS. Sci. Rep. 5, 9991 (2015).

42. Li, J. et al. Serum-free culture alters the quantity and protein composition of neuroblastomaderived extracellular vesicles. J. Extracell. Vesicles 4, 26883 (2015).

43. Abramowicz, A., Widłak, P. \& Pietrowska, M. Different Types of Cellular Stress Affect the Proteome Composition of Small Extracellular Vesicles: A Mini Review. Proteomes 7, 23 (2019).

44. Royo, F., Théry, C., Falcón-Pérez, J. M., Nieuwland, R. \& Witwer, K. W. Methods for Separation and Characterization of Extracellular Vesicles: Results of a Worldwide Survey Performed by the ISEV Rigor and Standardization Subcommittee. Cells 9, 1955 (2020).

45. Zhang, P., Yeo, J. C. \& Lim, C. T. Advances in Technologies for Purification and Enrichment of Extracellular Vesicles. SLAS Technol. Transl. Life Sci. Innov. 24, 477-488 (2019).

46. Konoshenko, M. Y., Lekchnov, E. A., Vlassov, A. V. \& Laktionov, P. P. Isolation of Extracellular Vesicles: General Methodologies and Latest Trends. BioMed Res. Int. 2018, e8545347 (2018).

47. Yang, D. et al. Progress, opportunity, and perspective on exosome isolation - efforts for efficient exosome-based theranostics. Theranostics 10, 3684-3707 (2020).

48. Kurian, T. K., Banik, S., Gopal, D., Chakrabarti, S. \& Mazumder, N. Elucidating Methods for Isolation and Quantification of Exosomes: A Review. Mol. Biotechnol. 63, 249-266 (2021).

49. Moleirinho, M. G., Silva, R. J. S., Carrondo, M. J. T., Alves, P. M. \& Peixoto, C. Exosome-based therapeutics: Purification using semi-continuous multi-column chromatography. Sep. Purif. Technol. 224, 515-523 (2019).

50. Nordin, J. Z. et al. Ultrafiltration with size-exclusion liquid chromatography for high yield isolation of extracellular vesicles preserving intact biophysical and functional properties. Nanomedicine Nanotechnol. Biol. Med. 11, 879-883 (2015).

51. Gimona, M., Pachler, K., Laner-Plamberger, S., Schallmoser, K. \& Rohde, E. Manufacturing of Human Extracellular Vesicle-Based Therapeutics for Clinical Use. Int. J. Mol. Sci. 18, (2017).

52. Whittaker, T. E., Nagelkerke, A., Nele, V., Kauscher, U. \& Stevens, M. M. Experimental artefacts can lead to misattribution of bioactivity from soluble mesenchymal stem cell paracrine factors to extracellular vesicles. J. Extracell. Vesicles 9, 1807674 (2020).

53. Colao, I. L., Corteling, R., Bracewell, D. \& Wall, I. Manufacturing Exosomes: A Promising Therapeutic Platform. Trends Mol. Med. 24, 242-256 (2018).

54. Lambrechts, T. et al. Large-Scale Mesenchymal Stem/Stromal Cell Expansion: A Visualization Tool for Bioprocess Comparison. Tissue Eng. Part B Rev. 22, 485-498 (2016).

55. Schallmoser, K. et al. Human platelet lysate can replace fetal bovine serum for clinical-scale expansion of functional mesenchymal stromal cells. Transfusion (Paris) 47, 1436-1446 (2007).

56. Hanley, P. J. et al. Efficient manufacturing of therapeutic mesenchymal stromal cells with the use of the Quantum Cell Expansion System. Cytotherapy 16, 1048-1058 (2014).

57. Mitchell, J. P., Court, J., Mason, M. D., Tabi, Z. \& Clayton, A. Increased exosome production from tumour cell cultures using the Integra CELLine Culture System. J. Immunol. Methods 335, 98105 (2008). 
58. Jeppesen, D. K. et al. Quantitative proteomics of fractionated membrane and lumen exosome proteins from isogenic metastatic and nonmetastatic bladder cancer cells reveal differential expression of EMT factors. Proteomics 14, 699-712 (2014).

59. Madel, R. J. et al. Independent human mesenchymal stromal cell-derived extracellular vesicle preparations differentially affect symptoms in an advanced murine Graft-versus-Host-Disease model. bioRxiv 2020.12.21.423658 (2020) doi:10.1101/2020.12.21.423658.

60. Andriolo, G. et al. Exosomes From Human Cardiac Progenitor Cells for Therapeutic Applications: Development of a GMP-Grade Manufacturing Method. Front. Physiol. 9, (2018).

61. Exosomes with Hollow Fiber. FiberCell Systems https://www.fibercellsystems.com/exosomeshollow-fiber/. Last access 30 March 2021.

62. Watson, D. C. et al. Efficient production and enhanced tumor delivery of engineered extracellular vesicles. Biomaterials 105, 195-205 (2016).

63. Patel, D. B. et al. Impact of cell culture parameters on production and vascularization bioactivity of mesenchymal stem cell-derived extracellular vesicles. Bioeng. Transl. Med. 2, 170179 (2017).

64. Yan, L. \& Wu, X. Exosomes produced from 3D cultures of umbilical cord mesenchymal stem cells in a hollow-fiber bioreactor show improved osteochondral regeneration activity. Cell Biol. Toxicol. 36, 165-178 (2020).

65. Yoo, K. W. et al. Large-Scale Preparation of Extracellular Vesicles Enriched with Specific microRNA. Tissue Eng. Part C Methods 24, 637-644 (2018).

66. Cartridges. FiberCell Systems https://www.fibercellsystems.com/products/cartridges/. Last access 30 March 2021.

67. SciVario ${ }^{\circledast}$ twin: The Next-Generation of Bioreactor Control Systems - Eppendorf. https://www.eppendorf.com/FR-fr/scivario/. Last access 30 March 2021.

68. Saha, B., Momen-Heravi, F., Kodys, K. \& Szabo, G. MicroRNA Cargo of Extracellular Vesicles from Alcohol-exposed Monocytes Signals Naive Monocytes to Differentiate into M2 Macrophages. J. Biol. Chem. 291, 149-159 (2016).

69. Jang, S. C. et al. Bioinspired Exosome-Mimetic Nanovesicles for Targeted Delivery of Chemotherapeutics to Malignant Tumors. ACS Nano 7, 7698-7710 (2013).

70. Song, Y. et al. The emerging role of exosomes as novel therapeutics: Biology, technologies, clinical applications, and the next. Am. J. Reprod. Immunol. n/a, e13329.

71. Carswell, K. S. \& Papoutsakis, E. T. Culture of human T cells in stirred bioreactors for cellular immunotherapy applications: Shear, proliferation, and the IL-2 receptor. Biotechnol. Bioeng. $\mathbf{6 8}$, 328-338 (2000).

72. Palviainen, M. et al. Metabolic signature of extracellular vesicles depends on the cell culture conditions. J. Extracell. Vesicles 8, 1596669 (2019).

73. Thangaraju, K., Neerukonda, S. N., Katneni, U. \& Buehler, P. W. Extracellular Vesicles from Red Blood Cells and Their Evolving Roles in Health, Coagulopathy and Therapy. Int. J. Mol. Sci. 22, (2020).

74. Zhang, D. X., Kiomourtzis, T., Lam, C. K. \& Le, M. T. N. The Biology and Therapeutic Applications of Red Blood Cell Extracellular Vesicles. Erythrocyte (2018) doi:10.5772/intechopen.81758.

75. Beer, L., Mildner, M., Gyöngyösi, M. \& Ankersmit, H. J. Peripheral blood mononuclear cell secretome for tissue repair. Apoptosis Int. J. Program. Cell Death 21, 1336-1353 (2016). 
76. Gardiner, C. et al. Techniques used for the isolation and characterization of extracellular vesicles: results of a worldwide survey. J. Extracell. Vesicles 5, 32945 (2016).

77. Zhu, J. et al. Myocardial reparative functions of exosomes from mesenchymal stem cells are enhanced by hypoxia treatment of the cells via transferring microRNA-210 in an nSMase2dependent way. Artif. Cells Nanomedicine Biotechnol. 46, 1659-1670 (2018).

78. Samoylenko, A. et al. The effect of hypoxia on extracellular vesicles secretion from renalcarcinoma and normal embryonic kidney cells. J. Extracell. Vesicles 7, 126-127 (2018).

79. Parolini, l. et al. Microenvironmental pH is a key factor for exosome traffic in tumor cells. J. Biol. Chem. 284, 34211-34222 (2009).

80. Ban, J.-J., Lee, M., Im, W. \& Kim, M. Low pH increases the yield of exosome isolation. Biochem. Biophys. Res. Commun. 461, 76-79 (2015).

81. Chen, T., Guo, J., Yang, M., Zhu, X. \& Cao, X. Chemokine-containing exosomes are released from heat-stressed tumor cells via lipid raft-dependent pathway and act as efficient tumor vaccine. J. Immunol. Baltim. Md 1950 186, 2219-2228 (2011).

82. Zhao, Z. et al. Low-intensity ultrasound radiation increases exosome yield for efficient drug delivery. J. Drug Deliv. Sci. Technol. 57, 101713 (2020).

83. Bagheri, H. S. et al. Low-level laser irradiation at a high power intensity increased human endothelial cell exosome secretion via Wnt signaling. Lasers Med. Sci. 33, 1131-1145 (2018).

84. Wen, Y. et al. Factors influencing the measurement of the secretion rate of extracellular vesicles. Analyst 145, 5870-5877 (2020).

85. Park, D. J. et al. Improvement of stem cell-derived exosome release efficiency by surfacemodified nanoparticles. J. Nanobiotechnology 18, 178 (2020).

86. Emam, S. E. et al. A Novel Strategy to Increase the Yield of Exosomes (Extracellular Vesicles) for an Expansion of Basic Research. Biol. Pharm. Bull. 41, 733-742 (2018).

87. Garcia, N. A., Ontoria-Oviedo, I., González-King, H., Diez-Juan, A. \& Sepúlveda, P. Glucose Starvation in Cardiomyocytes Enhances Exosome Secretion and Promotes Angiogenesis in Endothelial Cells. PloS One 10, e0138849 (2015).

88. Patel, D. B., Luthers, C. R., Lerman, M. J., Fisher, J. P. \& Jay, S. M. Enhanced extracellular vesicle production and ethanol-mediated vascularization bioactivity via a 3D-printed scaffoldperfusion bioreactor system. Acta Biomater. 95, 236-244 (2019).

89. Gazeau, F., Silva, A. K. A., Merten, O.-W., Wilhelm, C. \& Piffoux, M. Fluid System for Producing Extracellular Vesicles and Associated Method. (2019).

90. Grangier, A., Wilhelm, C., Gazeau, F. \& Silva, A. High yield and scalable EV production from suspension cells triggered by turbulence in a bioreactor. (2020) doi:10.1016/j.jcyt.2020.03.061.

91. Berger, A. et al. Local administration of stem cell-derived extracellular vesicles in a thermoresponsive hydrogel promotes a pro-healing effect in a rat model of colo-cutaneous postsurgical fistula. Nanoscale 13, 218-232 (2021).

92. Pinto, A. et al. Immune Reprogramming Precision Photodynamic Therapy of Peritoneal Metastasis by Scalable Stem-Cell-Derived Extracellular Vesicles. ACS Nano 15, 3251-3263 (2021).

93. Vion, A.-C. et al. Shear stress regulates endothelial microparticle release. Circ. Res. 112, 1323-1333 (2013).

94. Ab Razak, N. S., Ab Mutalib, N. S., Mohtar, M. A. \& Abu, N. Impact of Chemotherapy on Extracellular Vesicles: Understanding the Chemo-EVs. Front. Oncol. 9, (2019).

95. Aubertin, K. et al. Massive release of extracellular vesicles from cancer cells after photodynamic treatment or chemotherapy. Sci. Rep. 6, 35376 (2016). 
96. McBroom, A. J. \& Kuehn, M. J. Release of outer membrane vesicles by Gram-negative bacteria is a novel envelope stress response. Mol. Microbiol. 63, 545-558 (2007).

97. Wang, X., Koffi, P. F., English, O. F. \& Lee, J. C. Staphylococcus aureus Extracellular Vesicles: A Story of Toxicity and the Stress of 2020. Toxins 13, 75 (2021).

98. Hacker, S. et al. Paracrine Factors from Irradiated Peripheral Blood Mononuclear Cells Improve Skin Regeneration and Angiogenesis in a Porcine Burn Model. Sci. Rep. 6, 25168 (2016).

99. Kasiri, M. M. et al. Dying blood mononuclear cell secretome exerts antimicrobial activity. Eur. J. Clin. Invest. 46, 853-863 (2016).

100. Cho, A., Jantschitsch, C. \& Knobler, R. Extracorporeal Photopheresis-An Overview. Front. Med. 5, (2018).

101. Lu, M. \& Huang, Y. Bioinspired exosome-like therapeutics and delivery nanoplatforms. Biomaterials 242, 119925 (2020).

102. Kalimuthu, S. et al. A New Approach for Loading Anticancer Drugs Into Mesenchymal Stem Cell-Derived Exosome Mimetics for Cancer Therapy. Front. Pharmacol. 9, (2018).

103. Jo, W. et al. Microfluidic fabrication of cell-derived nanovesicles as endogenous RNA carriers. Lab Chip 14, 1261-1269 (2014).

104. Goh, W. J. et al. Bioinspired Cell-Derived Nanovesicles versus Exosomes as Drug Delivery Systems: a Cost-Effective Alternative. Sci. Rep. 7, 14322 (2017).

105. Yang, Z. et al. Functional exosome-mimic for delivery of siRNA to cancer: in vitro and in vivo evaluation. J. Controlled Release 243, 160-171 (2016).

106. Wu, J.-Y. et al. Exosome-Mimetic Nanovesicles from Hepatocytes promote hepatocyte proliferation in vitro and liver regeneration in vivo. Sci. Rep. 8, 2471 (2018).

107. Toledano Furman, N. E. et al. Reconstructed Stem Cell Nanoghosts: A Natural Tumor Targeting Platform. Nano Lett. 13, 3248-3255 (2013).

108. Ingato, D., Edson, J. A., Zakharian, M. \& Kwon, Y. J. Cancer Cell-Derived, Drug-Loaded Nanovesicles Induced by Sulfhydryl-Blocking for Effective and Safe Cancer Therapy. ACS Nano 12, 9568-9577 (2018).

109. Choo, Y. W. et al. M1 Macrophage-Derived Nanovesicles Potentiate the Anticancer Efficacy of Immune Checkpoint Inhibitors. ACS Nano 12, 8977-8993 (2018).

110. Zhu, L. et al. Novel alternatives to extracellular vesicle-based immunotherapy - exosome mimetics derived from natural killer cells. Artif. Cells Nanomedicine Biotechnol. 46, S166-S179 (2018).

111. Hwang, J. et al. Reprogramming of macrophages with macrophage cell membrane-derived nanoghosts. Nanoscale Adv. 2, 5254-5262 (2020).

112. Krishnamurthy, S. et al. Monocyte cell membrane-derived nanoghosts for targeted cancer therapy. Nanoscale 8, 6981-6985 (2016).

113. Oieni, J. et al. Nano-Ghosts: Biomimetic membranal vesicles, technology and characterization. Methods 177, 126-134 (2020).

114. Thone, M. N. \& Kwon, Y. J. Extracellular blebs: Artificially-induced extracellular vesicles for facile production and clinical translation. Methods San Diego Calif 177, 135-145 (2020).

115. Serrano-Pertierra, E. et al. Characterization of Plasma-Derived Extracellular Vesicles Isolated by Different Methods: A Comparison Study. Bioengineering 6, 8 (2019).

116. Vestad, B. et al. Size and concentration analyses of extracellular vesicles by nanoparticle tracking analysis: a variation study. J. Extracell. Vesicles 6, 1344087 (2017).

117. Webber, J. \& Clayton, A. How pure are your vesicles? J. Extracell. Vesicles 2, 19861 (2013). 
118. Serrano-Pertierra, E. et al. Extracellular Vesicles: Current Analytical Techniques for Detection and Quantification. Biomolecules 10, 824 (2020).

119. Brennan, K. et al. A comparison of methods for the isolation and separation of extracellular vesicles from protein and lipid particles in human serum. Sci. Rep. 10, 1039 (2020).

120. Monguió-Tortajada, M., Gálvez-Montón, C., Bayes-Genis, A., Roura, S. \& Borràs, F. E. Extracellular vesicle isolation methods: rising impact of size-exclusion chromatography. Cell. Mol. Life Sci. 76, 2369-2382 (2019).

121. Baranyai, T. et al. Isolation of Exosomes from Blood Plasma: Qualitative and Quantitative Comparison of Ultracentrifugation and Size Exclusion Chromatography Methods. PLOS ONE 10, e0145686 (2015).

122. Cao, J. et al. Three-dimensional culture of MSCs produces exosomes with improved yield and enhanced therapeutic efficacy for cisplatin-induced acute kidney injury. Stem Cell Res. Ther. 11, 206 (2020).

123. Kaneti, L. et al. Nanoghosts as a Novel Natural Nonviral Gene Delivery Platform Safely Targeting Multiple Cancers. Nano Lett. 16, 1574-1582 (2016).

124. Codiak Reports Positive Initial Phase 1 Results for exolL-12 $2^{\mathrm{TM}}$ Demonstrating Tolerability and Absence of Systemic IL-12 Exposure in Healthy Volunteers | Codiak BioSciences.

https://ir.codiakbio.com/news-releases/news-release-details/codiak-reports-positive-initialphase-1-results-exoil-12tm/. Last access 30 March 2021.

125. Dooley, K. et al. A Versatile Platform for Generating Engineered Extracellular Vesicles with Defined Therapeutic Properties. Mol. Ther. (2021) doi:10.1016/j.ymthe.2021.01.020.

126. Volchkov, S. E. \& Tyumina O. V. METHOD OF PRODUCING AND CONCENTRATING microRNACONTAINING EXOSOMES OF MULTIPOTENT MESENCHYMAL STROMAL CELLS FOR USE IN COSMETIC AND MEDICINAL AGENTS FOR STIMULATING REGENERATIVE PROCESSES AND SLOWING DOWN AGING PROCESSES. (2019).

127. Iravani, S. \& Varma, R. S. Plant-Derived Edible Nanoparticles and miRNAs: Emerging Frontier for Therapeutics and Targeted Drug-Delivery. ACS Sustain. Chem. Eng. 7, 8055-8069 (2019).

128. Exopharm has just dosed its first patient in a wound-healing study. https://exopharm.com/exopharm-has-just-dosed-its-first-patient-in-a-wound-healing-study/. Last access 30 March 2021.

129. Mildner, M. et al. Secretome of peripheral blood mononuclear cells enhances wound healing. Plos One 8, e60103 (2013). 